\title{
Investigation of the Chemical Purity of Silicon Surfaces Reacted with Liquid Methanol
}

\author{
David J. Michalak, ${ }^{\dagger, \S}$ Sandrine Rivillon Amy, ${ }^{\dagger, \perp}$ A. Estève, ${ }^{\ddagger}$ and Yves J. Chabal ${ }^{*, \dagger, \|}$ \\ Department of Chemistry and Chemical Biology, Rutgers University, Piscataway, New Jersey 08502, \\ Department of Materials Science and Engineering, University of Texas at Dallas, Richardson, Texas 75080, \\ and Laboratoire d'Analyse et d'Architecture des Systèmes-CNRS, University of Toulouse, \\ 31077 Toulouse, France
}

Received: April 8, 2008

\begin{abstract}
The reaction of hydrogen-terminated $\mathrm{Si}(111)$ and oxide-terminated silicon surfaces with neat anhydrous liquid methanol $\left(\mathrm{CH}_{3} \mathrm{OH}\right)$ has been studied with Fourier transform infrared spectroscopy (FTIR) as a function of solution temperature and immersion time. At $65^{\circ} \mathrm{C}$, reaction of atomically smooth $\mathrm{H}-\mathrm{Si}(111)$ surfaces with $\mathrm{CH}_{3} \mathrm{OH}$ (1) results in partially methoxylated silicon surfaces that are free of any detectable subsurface oxidation ( $\mathrm{Si}-\mathrm{O}-\mathrm{Si}$ bonds); this is in contrast to observable oxidation found after similar reactions on $\mathrm{H}-\mathrm{Si}(100)$ surfaces. At long reaction times $(t>3 \mathrm{~h})$, the $\mathrm{Si}(111)$ surface saturates with $\mathrm{Si}_{-}-\mathrm{OCH}_{3}$ sites at a coverage of approximately $30 \%$ of a monolayer, with the residual $\sim 70 \%$ comprised of unreacted $\mathrm{Si}-\mathrm{H}$ sites. The lack of any detectable silicon oxide makes it possible to conclude the following: (i) Reaction mechanisms involving insertion of oxygen atoms from the $\mathrm{CH}_{3} \mathrm{OH}$ molecule into the subsurface $\mathrm{Si}-\mathrm{Si}$ back bonds cannot be dominant for (111)-oriented silicon under these conditions. (ii) The vibrational modes of the oxide-free surface are very sharp and can be clearly distinguished from blue-shifted modes observed for methoxyl groups chemisorbed on oxidized surfaces. For surfaces that display subsurface oxidation, no evidence for oxygen atoms directly below atop $\mathrm{Si}-\mathrm{H}$ sites has been observed. Instead, FTIR analysis demonstrates that subsurface oxidation selectively exists underneath atop $\mathrm{Si}_{-} \mathrm{OCH}_{3}$ sites. Finally, $\mathrm{H}$-terminated oxide surfaces, prepared by reacting trichlorosilanes on $\mathrm{OH}$-terminated $\mathrm{SiO}_{2}$ surfaces, react with methanol to form a methoxy-terminated oxide surface.
\end{abstract}

\section{Introduction}

Careful chemical control over surfaces is important for the next generation of semiconductor devices. As device sizes get smaller, the surface-area-to-volume ratio increases, and custom control over the surface chemistry is required in order to optimize the desired performance. For example, untreated subsurface oxidation often compromises the performance of electronic devices ${ }^{1-3}$ and optical sensors ${ }^{4,5}$ and is particularly important for small devices such as nanowires. ${ }^{6}$ Chemical modification ${ }^{7,8}$ is used to form surfaces of high electrical quality that resist oxide growth. ${ }^{9-17}$ Surface chemistry can also be employed to adjust the electrical performance by modifying interfacial electron transfer kinetics ${ }^{17-20}$ and/or to adjust the dominant electron-hole recombination mechanisms. ${ }^{21,22}$ Chemical modification of silicon or silica surfaces with functional end groups is also employed for antistiction coatings in devices for microelectromechanical systems (MEMS) ${ }^{23-25}$ or to enable specific binding interactions to relevant molecules or proteins for various sensing applications. ${ }^{4,16,26-31}$ Despite the wide applicability of surface chemistry, the chemical stability of functionalized surfaces is, however, of concern because they are often stable only over a limited working range of temperature, ${ }^{32,33}$ air composition, physiological conditions, ${ }^{5}$ or

\footnotetext{
* To whom correspondence should be addressed. E-mail: chabal@ utdallas.edu.

${ }^{\dagger}$ Rutgers University.

" University of Texas at Dallas.

$¥$ University of Toulouse.

$\S$ Current address: Department of Chemistry, University of California, Berkeley, Berkeley, CA 94720.

${ }^{\perp}$ Current address: Material Research Center, Air Products and Chemicals Inc., Allentown, PA 18195.
}

pH values. ${ }^{34}$ Thus, understanding the chemical behavior of silicon surfaces with regard to the chemical and electrical stability is important for future technological developments.

At the atomic level, chemical modification of the surface occurs through the formation of $\mathrm{Si}-\mathrm{C}, \mathrm{Si}-\mathrm{O}$, or, occasionally, $\mathrm{Si}-\mathrm{N}$ bonds. ${ }^{35-37}$ It is the stability of these "first bonds" that determines the stability of the interface and electrical performance. Although the $\mathrm{Si}-\mathrm{C}$ bond is not too strong from a thermodynamic standpoint, the surfaces that result from these terminations appear incredibly inert, ${ }^{9}, 13-15,38$ most likely for kinetic reasons. $\mathrm{Si}-\mathrm{O}$ bonds are more thermodynamically stable, and chemical functionalization based on $\mathrm{Si}-\mathrm{O}$ linkages are ubiquitous in surface adsorbed monolayer (SAM) applications $s^{4,16,34,39-44}$ because of the ease in forming such surfaces. Such linkers are attached through reaction of the surface with alcohols, ${ }^{45-51}$ aldehydes ${ }^{45,52,53}$ and chloro- or alkoxy-silanes. ${ }^{4,16,42,43}$ There is considerable concern about the oxidation of the underlying silicon surface; in some cases, the oxidation dominates the SAM binding process, and surfaces must be preoxidized and bonded to large adsorbates in order to achieve stability. ${ }^{4,16}$

We have chosen a system that allows the fundamentals of silicon surface chemistry to be investigated at a very high level of resolution. First, atomically smooth hydrogen-terminated $\mathrm{Si}(111)$ surfaces have been used because of the simplicity and homogeneity of the surface. Proper etching of $\mathrm{Si}(111)$ surfaces leads to atomically smooth terraces (covering more than $99 \%$ of the surface), which contain a homogeneous array of identical $\mathrm{Si}-\mathrm{H}$ bonds oriented normal to the surface. ${ }^{54}$ This surface thus provides essentially only one reactant, which simplifies the number of possible reaction products. Second, the choice of methanol is critical. It is the smallest molecule, hence with the 
fewest number of vibrational modes, that contains both a hydrophobic $\left(\mathrm{CH}_{3}\right)$ terminus and a hydrophilic $(\mathrm{OH})$ terminus. In addition to acting as a model for the variety of $\mathrm{OH}$-containing chemicals used in the formation of many SAMs, alcohols such as methanol are also important as rinsing agents or as reaction solvents. In some cases, the use of alcohols as solvents has been shown to compete with the preferred reaction pathway. ${ }^{55}$ Additionally, alcohols are often added to various etching solutions in order to break the surface tension and allow for desired structures (of certain porosity) to be made, ${ }^{4,16,56,57}$ in these situations, the surface interaction with the alcohol is significant. ${ }^{58}$ Methanol can thus act as a suitable model to understand fundamental surface chemistry for a number of relevant applications. Third, advances in data acquisition technology have allowed Fourier transform infrared spectroscopy to probe bonding interactions of submonolayer surface species with high resolution. Thus, it is the combination of the homogeneity of the $\mathrm{H}-\mathrm{Si}(111)$ surface, the broadband sensitivity of transmission mode FTIR, and the spectral simplicity of methanol that allows new insights in surface chemistry to be obtained.

We have previously shown using FTIR analysis that neat anhydrous liquid methanol reacts with $\mathrm{H}$-terminated silicon surfaces, ${ }^{59}$ but important questions about the reaction mechanism as well as the position of the observed oxidation still remain. This paper systematically investigates the methoxylation reaction on both H-terminated and oxidized Si surfaces. Specifically, we determine the optimum conditions for forming a uniform submonolayer coverage of methoxyl groups without any detectable silicon oxide ( $<\sim 3 \%$ of a monolayer). ${ }^{60}$ Such surfaces, achieved by $\geq 3 \mathrm{~h}$ immersion in methanol at $65{ }^{\circ} \mathrm{C}$, display a maximum of $\sim 30 \%$ of a monolayer of $\mathrm{Si}-\mathrm{OCH}_{3}$ sites interspersed between the remaining $\sim 70 \%$ of a monolayer of $\mathrm{Si}-\mathrm{H}$ sites. We also study the physical location of the subsurface oxidation that forms under certain conditions. Finally, we demonstrate that trichlorosilane-derivatized oxide-terminated surfaces also exhibit relatively high reactivity with methanol.

\section{Experimental Section}

A. Materials and Methods. Anhydrous methanol $\left(\mathrm{CH}_{3} \mathrm{OH}\right)$ (99.8\%), trichlorosilane (TCS, 99\%), and anhydrous toluene were purchased from Aldrich. These chemicals were used as received and were placed inside a $\mathrm{N}_{2}(\mathrm{~g})$-purged glovebox prior to use. Aqueous ammonium fluoride ( $40 \%$ by weight) and aqueous hydrofluoric acid ( $49 \%$ by weight) were obtained from J.T. Baker. Aqueous hydrogen peroxide (30\% by weight) and concentrated $(18 \mathrm{M})$ sulfuric acid were obtained from EM science. CAUTION: concentrated sulfuric acid is highly toxic and corrosive and can cause serious burns. Fluoride-containing solutions such as $11 \mathrm{M}$ (40\% by weight) $\mathrm{NH}_{4} \mathrm{~F}$, buffered $\mathrm{HF}$, and $27 M$ (48\% by weight) $H F$ pose a serious contact hazard. Hydrofluoric acid is highly toxic and corrosive and may cause serious burns which may not be immediately painful or visible. Fluoride ions readily penetrate the skin and can cause destruction of deep tissue and bone. All $\mathrm{H}_{2} \mathrm{O}$ is deionized with a resistivity of $18.2 \mathrm{M} \Omega \mathrm{cm}$.

N-type (phosphorus-doped, resistivity $\sim 24-34 \Omega$-cm) floatzone $\mathrm{Si}(111)$ wafers, polished on both sides, were cut into 2 $\mathrm{cm} \times 5 \mathrm{~cm}$ pieces for transmission mode infrared analysis. P-type (boron doped, resistivity $10 \Omega$-cm) float-zone Si(100) wafers, also polished on both sides, were obtained with an initially grown $25-60 \AA$ thick terminating oxide. These oxideterminated samples were cleaned using the RCA procedure that involved a $10 \mathrm{~min}$ exposure to an $80{ }^{\circ} \mathrm{C} \mathrm{SC1}$ solution (4:1:1
$\mathrm{H}_{2} \mathrm{O}: 30 \% \mathrm{H}_{2} \mathrm{O}_{2}(\mathrm{aq})$ : concentrated $\mathrm{NH}_{4} \mathrm{OH}(\mathrm{aq})$ ), followed by a rinsing step using $1 \mathrm{~L}$ of $\mathrm{H}_{2} \mathrm{O}$, a 10 min exposure to an $80{ }^{\circ} \mathrm{C}$ SC2 solution (4:1:1 $\mathrm{H}_{2} \mathrm{O}: 30 \% \mathrm{H}_{2} \mathrm{O}_{2}(\mathrm{aq})$ :concentrated $\mathrm{HCl}(\mathrm{aq})$ ), and a final rinsing step using $1 \mathrm{~L}$ of $\mathrm{H}_{2} \mathrm{O}$. $\mathrm{Si}(100)$ samples were hydrogen-terminated by a $30 \mathrm{~s}$ dip in $10-20 \% \mathrm{HF}(\mathrm{aq})$ followed by a $10 \mathrm{~s} \mathrm{H}_{2} \mathrm{O}$ rinse. $\mathrm{Si}(111)$ samples were hydrogen-terminated by a $30 \mathrm{~s}$ dip in $10-20 \% \mathrm{HF}(\mathrm{aq})$ followed by a $2.5 \mathrm{~min}$ dip in $40 \% \mathrm{NH}_{4} \mathrm{~F}(\mathrm{aq})$, and a final rinse in $\mathrm{H}_{2} \mathrm{O}$ for $10 \mathrm{~s}$. This latter procedure produces an atomically smooth (111)-oriented surface for tens to hundreds of nanometers. ${ }^{54,61,62}$ Oxides were chemically grown on an atomically flat hydrogen-terminated $\mathrm{Si}(111)$ surface using either the SC1/SC2 procedure outlined above or a 10 min exposure to $100{ }^{\circ} \mathrm{C}$ solution of $4: 1$ concentrated (18 M) $\mathrm{H}_{2} \mathrm{SO}_{4}: 30 \% \quad \mathrm{H}_{2} \mathrm{O}_{2}$ (aq) (hereafter referred to as piranha solution). Oxide surfaces grown from the piranha clean typically produced FTIR spectra that exhibited less hydrocarbon contamination. Silicon samples of (111)-orientation were often reused since an atomically flat surface could be prepared between subsequent experiments. Si(100) surfaces were not reused since continued $\mathrm{HF}(\mathrm{aq})$-etching and oxidation steps could increase the surface roughness.

Data were recorded in the dry $\mathrm{N}_{2}(\mathrm{~g})$-purged bench of a Fourier transform infrared (FTIR) spectrometer (Nicolet 6700, Nexus 670, Magna 860). Spectra were obtained with a nominal $4 \mathrm{~cm}^{-1}$ resolution between 400 and $4000 \mathrm{~cm}^{-1}$ in transmission mode, at an angle of incidence of $74^{\circ}$ (Brewster angle for silicon) with respect to the $\mathrm{Si}$ surface normal. A room temperature pyroelectric detector (DTGS) was used for data collection. Five consecutive loops, each consisting of 1000 single beam spectral scans, were obtained for each sample. References were either oxide-terminated or freshly etched hydrogen-terminated surfaces, as appropriate. The absorbance spectra were processed by subtracting water vapor and $\mathrm{CO}_{2}(\mathrm{~g})$ peaks and then by flattening the baseline to remove drifts. Omnic software was used to integrate the peak areas, and, when appropriate, peaks were fitted using Origin software.

Reactions were performed in $2.5 \mathrm{~cm}$ diameter $\times 15 \mathrm{~cm}$ glass tubes. These tubes were initially cleaned with aqua regia, followed by a 10 min clean with piranha solution to remove traces of metallic and carbon-containing contamination from the surfaces of the glass. The tubes were then rinsed with copious $\mathrm{H}_{2} \mathrm{O}$, fully dried using a heat gun, and brought into a nitrogen glovebox. For reactions performed at elevated temperatures, the tubes were placed into an aluminum heating block with a $2.6 \mathrm{~cm}$ diameter $\times 5 \mathrm{~cm}$ deep hole that fit the tube such that a silicon sample could be heated evenly along its entire length. The temperature of the solution was measured by a thermocouple probe that was placed between the tube and the aluminum block, and a feedback controller was used to keep the temperature constant. Separate reaction tubes were used for methanol and TCS/toluene solutions. A glass tube containing a given reaction solution was preheated to the temperature of interest for about $30 \mathrm{~min}$ before discarding that solution as a rinse waste. In addition to removing any impurities, this high temperature rinse would chemically modify the surface of the glass tube to be either methoxy-terminated (for methanol reactions) or hydrogen-terminated (for TCS/toluene reactions). Another allotment of solution was added subsequently and preheated to the desired temperature before the silicon sample was added. After immersion of the sample into the liquid, the tube was wrapped quickly with $\mathrm{Al}$ foil which provided both darkness (to minimize the effect of photogenerated charge carriers on the reaction rates) and thermal insulation. After the desired reaction time, the sample and solution were poured into 

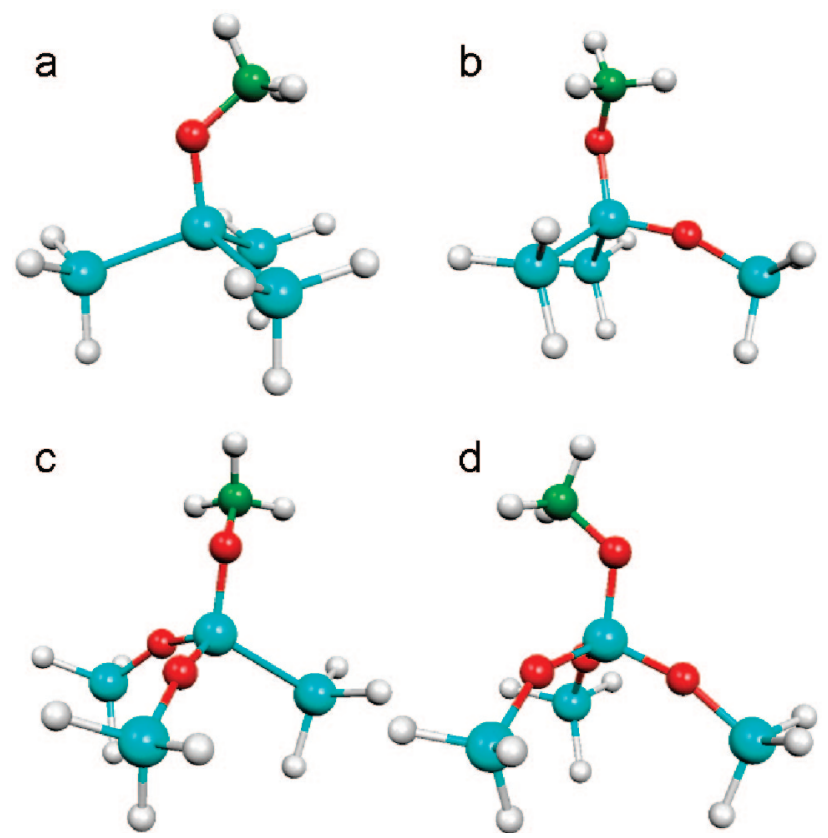

Figure 1. Models used in the calculations of infrared active modes for atop $\mathrm{Si}-\mathrm{OCH}_{3}$ groups containing either (a) zero, (b) one, (c) two, or (d) three oxygen atoms in the $\mathrm{Si}-\mathrm{Si}$ back bonds: $\mathrm{Si}$ (blue), $\mathrm{O}$ (red), $\mathrm{C}$ (green), and $\mathrm{H}$ (white).

a glass funnel, where the $\mathrm{Si}$ sample quickly dried. For reactions near room temperature, it was often necessary to angle and wave the sample to encourage evaporation of the liquid down to a corner of the sample that was not probed by FTIR. Once dry, samples were capped in centrifuge tubes under $\mathrm{N}_{2}(\mathrm{~g})$, removed from the glovebox, and carried to the spectrometer. When not in use, reaction tubes were capped with rubber stoppers, to prevent cross contamination, and stored in the glovebox.

B. First-Principles Calculations. All calculations were performed at the density functional level of theory using the Gaussian 03 package. ${ }^{63}$ All geometries and subsequent frequency determinations were calculated within the combined Becke's three parameters exchange hybrid functional B3LYP associated with the generalized gradient approximation (GGA) of Lee, Yang, and Parr. ${ }^{64,65}$ The electronic wave functions were described by the $6-31+\mathrm{G}^{* *}$ basis set. The cluster used to model the surface was composed of two silicon layers (4 atoms) with their valency satisfied by hydrogen atoms. The $\mathrm{Si}-\mathrm{H}$ bonds oriented toward the third subsurface layer were restricted to motions along the bulk $\mathrm{Si}-\mathrm{Si}$ crystal lattice directions in order to more closely mimic a real surface section and to allow for a precise definition of its normal orientation. The high frequency $\mathrm{CH}$ stretching region was scaled with reference to experimental $\mathrm{Si}-\mathrm{H}$ modes, having a typical scaling factor of 0.95 compared to calculated values. For the scaling studies involving the $\mathrm{Si}-\mathrm{H}$ terminal cluster, the three second-layer silicon atoms were terminated by $\mathrm{D}$ atoms, to prevent coupling interactions. The geometries and vibration frequencies were subsequently determined for a cluster model in which one, two, or three oxygen atoms were inserted into each of one, two or, three $\mathrm{Si}-\mathrm{Si}$ backbonds to the second layer of silicon atoms (Figure 1). The positions of the three subsurface silicon atoms were not fixed in the models containing subsurface oxygen atoms. For this reason, the $\mathrm{Si}-\mathrm{O}-\mathrm{Si}$ bonds of these models are not as strained as they would be for a real $\mathrm{Si}(111)$ surface with local patches of oxidation.

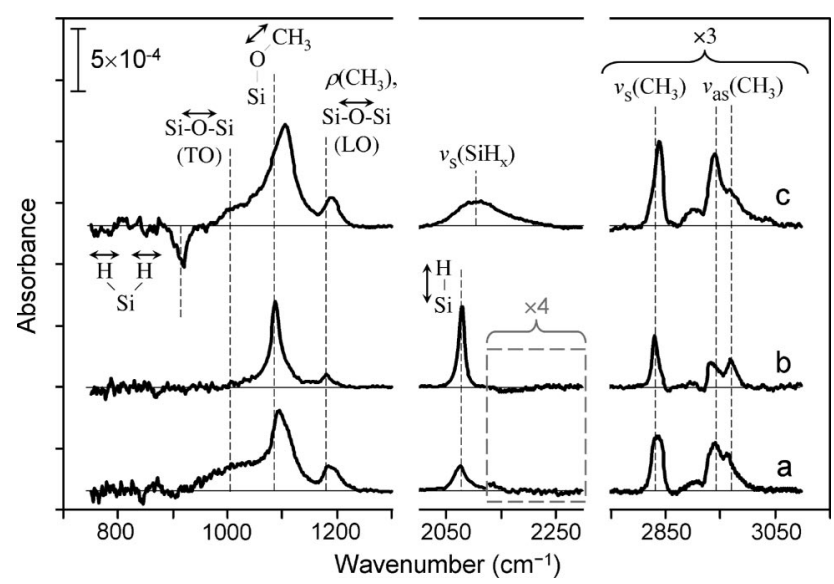

Figure 2. FTIR spectra of atomically smooth $\mathrm{H}-\mathrm{Si}(111)$ samples after exposure to $\mathrm{CH}_{3} \mathrm{OH}$ (1) in the dark for (a) 6 days at room temperature or (b) $12 \mathrm{~h}$ at $65^{\circ} \mathrm{C}$ or for (c) a $\mathrm{H}-\mathrm{Si}(100)$ sample exposed to $\mathrm{CH}_{3} \mathrm{OH}$ (l) in the dark for $3 \mathrm{~h}$ at $65^{\circ} \mathrm{C}$. The spectra for the $\mathrm{H}-\mathrm{Si}(100)$ surface and the room-temperature-reacted $\mathrm{H}-\mathrm{Si}(111)$ surface present observable subsurface oxidation $(\mathrm{Si}-\mathrm{O}-\mathrm{Si} \mathrm{LO}$ and $\mathrm{TO}$ modes), whereas no detectable oxide is observed upon reaction of $\mathrm{H}-\mathrm{Si}(111)$ with $65^{\circ} \mathrm{C}$ $\mathrm{CH}_{3} \mathrm{OH}(\mathrm{l})$. The single beam spectra are referenced relative to the native oxide-terminated surface within the spectral region of $2000-2300 \mathrm{~cm}^{-1}$ and are referenced relative to the atomically smooth $\mathrm{H}-\mathrm{Si}(111)$ surface in the spectral regions of $750-1300$ and $2800-3100 \mathrm{~cm}^{-1}$.

\section{Results}

In an attempt to optimize the methoxylation reaction with $\mathrm{H}$-terminated $\mathrm{Si}$ surfaces, i.e., to minimize the formation of $\mathrm{SiO}_{2}$, we first explore the solution temperature and immersion time in methanol. We then study the methoxylation of oxidized surfaces, including hydroxy- and hydrogen-terminated $\mathrm{SiO}_{2}$ surfaces.

A. Reactions of $\mathrm{H}-\mathrm{Si}(111)$ Surfaces with Methanol. Similar to recent results, ${ }^{59}$ Figure 2a displays the FTIR spectrum of an atomically smooth $\mathrm{H}-\mathrm{Si}(111)$ sample after exposure to $\mathrm{CH}_{3} \mathrm{OH}$ (l) in the dark for 6 days at room temperature. The exchange of some atop $\mathrm{Si}-\mathrm{H}$ groups with atop $\mathrm{Si}-\mathrm{OCH}_{3}$ groups is demonstrated by the appearance of a $\mathrm{CH}_{3}$ symmetric $(\sim 2840$ $\left.\mathrm{cm}^{-1}\right)$ and two $\mathrm{CH}_{3}$ asymmetric $\left(\sim 2940\right.$ and $\left.\sim 2980 \mathrm{~cm}^{-1}\right)$ stretching modes, a decrease in the intensity of, and a red-shift in, the $\mathrm{Si}-\mathrm{H}$ stretching mode $\left(\sim 2080 \mathrm{~cm}^{-1}\right)$, the appearance of the $\mathrm{CH}_{3}$ umbrella distortion $\left(1190 \mathrm{~cm}^{-1}\right)$, and the appearance of a complex mode involving an $\mathrm{O}-\mathrm{C}$ stretching motion coupled with a $\mathrm{C}-\mathrm{H}$ bending motion $\left(\sim 1090 \mathrm{~cm}^{-1}\right) .47,49,50,59,66$ The broadening (the full width at half-max increases up to $20 \mathrm{~cm}^{-1}$ ) and red-shifting (by about $6 \mathrm{~cm}^{-1}$ ) of the remaining $\mathrm{Si}-\mathrm{H}$ stretching modes indicates that dipole-dipole coupling between neighboring $\mathrm{Si}-\mathrm{H}$ species is being disrupted. ${ }^{67-70}$ This observation is consistent with random exchange of $\mathrm{Si}-\mathrm{H}$ sites to $\mathrm{Si}-\mathrm{OCH}_{3}$ sites over the entire surface rather than the formation of separated domains of isolated $\mathrm{Si}-\mathrm{H}$ and $\mathrm{Si}-\mathrm{OCH}_{3}$ groups. There is observable oxidation of the silicon surface as evidenced by positive absorption modes at $\sim 1050 \mathrm{~cm}^{-1}$ and $\sim 1220 \mathrm{~cm}^{-1}$, which correspond to the asymmetric $\mathrm{Si}-\mathrm{O}-\mathrm{Si}$ transverse optical (TO) and $\mathrm{Si}-\mathrm{O}-\mathrm{Si}$ longitudinal optical (LO) stretching modes, respectively. ${ }^{71}$ The frequency of the LO mode indicates that the regions of oxide $\left(\mathrm{SiO}_{2}\right)$ are very small in physical size, ${ }^{72,73}$ possibly including as few as 10 oxygen atoms. ${ }^{74}$ This is consistent with scanning tunneling microscopy observations that oxidation of $\mathrm{H}-\mathrm{Si}(111)$ surfaces occurs in randomly distributed 10-20 ̊ diameter domains. ${ }^{75}$ Similar results have been found for the oxidation of ethyl-terminated $\mathrm{Si}(111)$ surfaces using scanning Auger microscopy. ${ }^{15}$ Interestingly, the $\mathrm{Si}-\mathrm{O}-\mathrm{Si}$ 


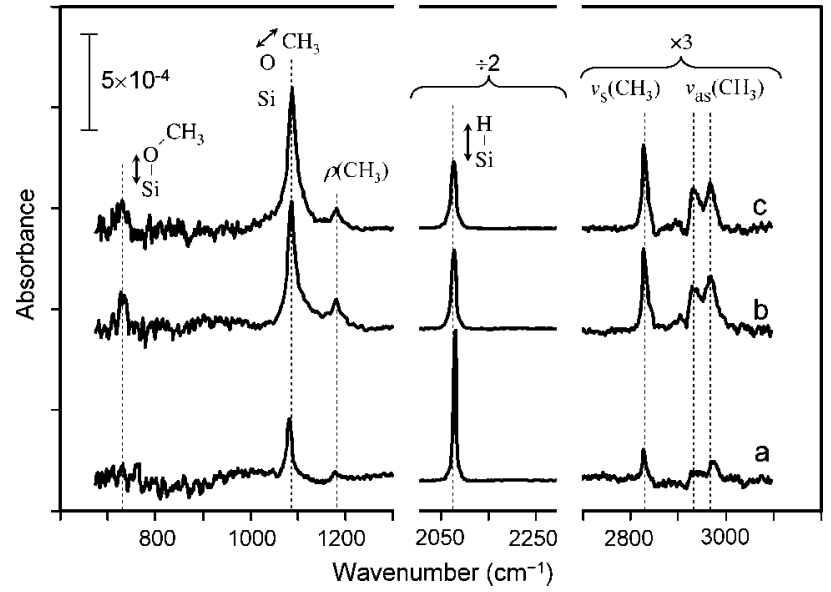

Figure 3. FTIR spectra of hydrogen-terminated $n$-Si(111) surfaces immersed in neat anhydrous $\mathrm{CH}_{3} \mathrm{OH}$ (l) in the dark at $65^{\circ} \mathrm{C}$ for (a) 10 min, (b) $3 \mathrm{~h}$, and (c) $12 \mathrm{~h}$. The reaction appears to be nearly complete after $3 \mathrm{~h}$ (Table 1). The single beam spectra are referenced relative to the native oxide-terminated surface within the spectral region of $2000-2300 \mathrm{~cm}^{-1}$ and are referenced relative to the atomically smooth $\mathrm{H}-\mathrm{Si}(111)$ surface in the spectral regions of $750-1300$ and $2800-3100$ $\mathrm{cm}^{-1}$.

oxidation species observed in Figure 2a do not reside underneath surface-bound $\mathrm{Si}-\mathrm{H}$ sites, because there is no observable absorption in the $2100-2300 \mathrm{~cm}^{-1}$ range, which corresponds to $\mathrm{Si}-\mathrm{H}$ species with oxygen inserted in the $\mathrm{Si}-\mathrm{Si}$ back bonds (hereafter referred to as $\mathrm{O}_{\mathrm{x}} \mathrm{Si}-\mathrm{H}$ species) $;{ }^{76}$ this spectral region is multiplied by a factor of 4 for the spectra of Figure 2, panels $a$ and $b$, for clarity. Based on the spectral noise rms of $(5 \pm 1)$ $\times 10^{-6}$ and an estimated signal-to-noise ratio of 4 necessary for detection, the $\mathrm{O}_{x} \mathrm{Si}-\mathrm{H}$ species must be less than $4 \%$ of a monolayer. While the amount of oxidation observed on these samples is variable, it is consistently larger than $4 \%$ of a monolayer (typically $30-100 \%$ of a monolayer for room temperature reactions), implying that $\mathrm{O}_{x} \mathrm{Si}-\mathrm{H}$ species should be observed out of the noise if the oxidation resides below $\mathrm{Si}-\mathrm{H}$ sites. The absence of $\mathrm{O}_{x} \mathrm{Si}-\mathrm{H}$ modes in this study is in contrast with experiments on $\mathrm{H}-\mathrm{Si}(111)$ samples exposed to gas-phase $\mathrm{O}_{2}$ or $\mathrm{H}_{2} \mathrm{O}$ at elevated temperatures. ${ }^{76}$ These results imply that different oxidation pathways exist between higher-temperature gas phase and lower-temperature solution phase systems.

When the $\mathrm{H}-\mathrm{Si}(111)$ surface is exposed to $65^{\circ} \mathrm{C} \mathrm{CH}_{3} \mathrm{OH}$ (1) in the dark for $12 \mathrm{~h}$, no detectable $\mathrm{SiO}_{2}$ modes are observed ${ }^{77}$ despite a similar $v_{\mathrm{s}}\left(\mathrm{CH}_{3}\right)$ intensity ( relative to the 6 day room-temperature reaction (c.f., Figure 2, panels $\mathrm{a}$ and $\mathrm{b}$, and the data in Table 1). In addition, the complex $\mathrm{O}-\mathrm{C}$ mode, the $\mathrm{CH}_{3}$ umbrella mode, the residual $\mathrm{Si}-\mathrm{H}$ stretching mode, and the $\mathrm{C}-\mathrm{H}$ stretching modes are all significantly spectrally sharper. The spectrum obtained after reaction of a hydrogen-terminated $\mathrm{Si}(100)$ surface with $65^{\circ} \mathrm{C}$ $\mathrm{CH}_{3} \mathrm{OH}$ (l) for $3 \mathrm{~h}$ in the dark is presented in Figure $2 \mathrm{c}$ for comparison. Although this spectrum presents visibly larger $\mathrm{C}-\mathrm{H}$ stretching and larger complex $\mathrm{O}-\mathrm{C}$ modes, suggesting a higher coverage of $\mathrm{Si}-\mathrm{OCH}_{3}$ sites, ${ }^{78}$ the modes are considerably broader with clearly detectable subsurface oxidation even under the same reaction conditions (e.g., oxygen- and watercontamination levels, temperature, and darkness) as the $\mathrm{Si}(111)$ surface of Figure $2 \mathrm{~b}$. The negative mode at $911 \mathrm{~cm}^{-1}$ (Figure 2c) is assigned to a loss in the $\mathrm{SiH}_{2}$ scissor mode (relative to the freshly etched hydrogen-terminated $\mathrm{Si}(100)$ surface used as a reference for this spectral region) due to reaction of the dihydride surface species with methanol. Correspondingly, the $2000-2300 \mathrm{~cm}^{-1} \mathrm{Si}-\mathrm{H}$ stretching region (relative to the oxide
TABLE 1: Stretching Mode $\operatorname{Areas}^{a}$ for $\mathrm{H}-\mathrm{Si}(111)$ as a Function of Reaction Time in $\mathrm{CH}_{3} \mathrm{OH}$ (l)

\begin{tabular}{|c|c|c|c|}
\hline surface treatment & $\begin{array}{l}\text { frac. } \mathrm{Si}-\mathrm{H} \\
\text { coverage }^{b}\end{array}$ & $\begin{array}{c}\text { complex } \mathrm{O}-\mathrm{C} \\
\left(\mathrm{mAU} \mathrm{cm} \mathrm{cm}^{-1}\right)\end{array}$ & $\begin{array}{c}v_{\mathrm{s}}\left(\mathrm{CH}_{3}\right) \\
\left(\mathrm{mAU} \mathrm{cm}^{-1}\right.\end{array}$ \\
\hline freshly etched & 1 & 0 & 0 \\
\hline $65^{\circ} \mathrm{C} \mathrm{Rxn}:$ & & & \\
\hline $10 \min \mathrm{CH}_{3} \mathrm{OH}$ & $0.90 \pm 0.04$ & $6 \pm 1$ & $1.6 \pm 0.4$ \\
\hline $3 \mathrm{~h} \mathrm{CH}_{3} \mathrm{OH}$ & $0.77 \pm 0.05$ & $23 \pm 1$ & $2.5 \pm 0.2$ \\
\hline $10-12 \mathrm{~h} \mathrm{CH}_{3} \mathrm{OH}$ & $0.72 \pm 0.03$ & $22 \pm 3$ & $2.9 \pm 0.6$ \\
\hline Room Temp Rxn: & & & \\
\hline $10 \min \mathrm{CH}_{3} \mathrm{OH}$ & $0.94 \pm 0.13$ & & $0.7 \pm 0.2$ \\
\hline $3 \mathrm{~h} \mathrm{CH}_{3} \mathrm{OH}$ & $0.85 \pm 0.10$ & $12 \pm 2$ & $1.2 \pm 0.4$ \\
\hline $24 \mathrm{~h} \mathrm{CH}_{3} \mathrm{OH}$ & $0.73 \pm 0.06$ & $25 \pm 3$ & $1.6 \pm 0.4$ \\
\hline 6 day $\mathrm{CH}_{3} \mathrm{OH}^{c}$ & $0.56 \pm 0.10$ & $21 \pm 7$ & $3.2 \pm 2.2$ \\
\hline
\end{tabular}

${ }^{a}$ The areas were evaluated for a $74^{\circ}$ angle of incidence relative to the surface normal, with the aperture $100 \%$ open, and exciting roughly $4 \mathrm{~cm}^{2}$ of the surface of the sample. The front and rear face of the surface are treated identically and both are absorbing light. ${ }^{b}$ The fractional $\mathrm{Si}-\mathrm{H}$ coverage values were calculated as the ratio of the area of the $\mathrm{H}-\mathrm{Si}$ stretching mode after a given surface treatment (referenced relative to the oxide spectrum of that sample) to the area under the initial freshly etched $\mathrm{H}-\mathrm{Si}$ stretching mode of that same sample (referenced relative to the oxide spectrum). ${ }^{c}$ The fractional $\mathrm{Si}-\mathrm{H}$ coverage below 0.7 is most likely attributed to the large amount of oxidation also observed on these samples and does not necessarily imply a higher $\mathrm{Si}-\mathrm{OCH}_{3}$ coverage. The $v_{\mathrm{s}}\left(\mathrm{CH}_{3}\right)$ mode areas are assumed to produce a more reliable comparison of the $\mathrm{Si}-\mathrm{OCH}_{3}$ coverage.

surface) is very broad after reaction as it contains modes corresponding to coupled and uncoupled $\mathrm{SiH}-, \mathrm{SiH}_{2}-$, and $\mathrm{SiH}_{3}-$ stretching modes ${ }^{79,80}$ in a variety of chemical environments.

Figure 3 displays the FTIR spectra of hydrogen-terminated $n$-Si(111) samples immersed in neat anhydrous $\mathrm{CH}_{3} \mathrm{OH}$ (1) in the dark at $65^{\circ} \mathrm{C}$ after reaction times of $10 \mathrm{~min}, 3 \mathrm{~h}$, or $12 \mathrm{~h}$. This study of immersion time shows that the complex $\mathrm{O}-\mathrm{C}$, $\mathrm{Si}-\mathrm{H}$, and $\mathrm{C}-\mathrm{H}$ stretching modes remain sharp with no detectable $\mathrm{SiO}_{2}$ modes over a wide range of reaction times; there are also no large shifts in the resonant frequencies. As opposed to the room temperature study previously reported, ${ }^{59}$ these spectra are obtained with a lower-noise detector that made it possible to observe the weak $\mathrm{Si}-\mathrm{O}$ stretching mode at $734 \mathrm{~cm}^{-1}$ (predicted by previous DFT calculations to be at $\sim 725 \mathrm{~cm}^{-1}$ ). ${ }^{59}$ Table 1 displays the area of the $\mathrm{Si}-\mathrm{H}, \mathrm{C}-\mathrm{H}$, and complex $\mathrm{O}-\mathrm{C}$ modes for each reaction time; the reaction with $65^{\circ} \mathrm{C}$ neat methanol appears to be nearly complete after $3 \mathrm{~h}$.

B. Reactions of Oxide Surfaces with Methanol. Although the subsurface oxide found on the room-temperature-reacted surfaces (Figure 2a) does not appear to reside below atop $\mathrm{Si}-\mathrm{H}$ sites, it could reside directly below atop $\mathrm{Si}-\mathrm{OCH}_{3}$ sites. FTIR analysis was performed on oxidized silicon surfaces in order to observe any changes in the stretching frequencies for such $\mathrm{Si}-\mathrm{OCH}_{3}$ sites (hereafter referred to as $\mathrm{O}_{x} \mathrm{Si}-\mathrm{OCH}_{3}$ sites). Figure 4 presents the FTIR spectra of a thin wet-chemically generated 5-10 $\AA$ thick oxide-terminated $n$-Si(111) surface immersed in neat anhydrous $\mathrm{CH}_{3} \mathrm{OH}$ (1) for $3 \mathrm{~h}$ at $65^{\circ} \mathrm{C}$. This oxide layer was generated by treating an atomically flat hydrogen-terminated $\mathrm{Si}(111)$ surface with a $10 \mathrm{~min}$ immersion in piranha solution. Figure $4 \mathrm{a}$ displays the low frequency absorbance spectrum of the $\mathrm{CH}_{3} \mathrm{OH}$-treated oxide surface relative to the initial oxide surface. Spectra b and c represent the piranha-grown oxide surface (gray) and the $\mathrm{CH}_{3} \mathrm{OH}$-treated oxide surface (black) each referenced relative to the initial atomically flat $\mathrm{H}-\mathrm{Si}(111)$ surface; both are divided by a factor of 2 and superimposed for clarity. Spectra $b$ and $c$ are included to demonstrate that the broad mode around $\sim 1050 \mathrm{~cm}^{-1}$ and 
TABLE 2: Observed and Calculated Modes for the Unoxidized $\mathrm{Si}_{3} \mathrm{Si}-\mathrm{OCH}_{3}$ and Oxidized $\mathrm{O}_{x} \mathrm{Si}-\mathrm{OCH}_{3} \mathrm{Species}$

\begin{tabular}{|c|c|c|c|c|c|c|c|c|}
\hline spectral assignment & $v_{\mathrm{obs}}$ & $v_{\text {theo }}$ & intensity $^{a}$ & angle $^{b}$ & orientation $^{c}$ & $v_{\mathrm{obs}}$ & $v_{\text {theo }}(1 / 2 / 3 \mathrm{O}$ in the backbonds $)$ & intensity $^{a}$ \\
\hline & \multicolumn{5}{|c|}{ unoxidized $\mathrm{Si}-\mathrm{OCH}_{3}\left(12 \mathrm{~h}\right.$ reaction at $\left.65^{\circ} \mathrm{C}\right)$} & \multicolumn{3}{|c|}{ oxidized $\mathrm{O}_{3} \mathrm{Si}-\mathrm{OCH}_{3}\left(3 \mathrm{~h}\right.$ reaction at $\left.65^{\circ} \mathrm{C}\right)$} \\
\hline$v_{\mathrm{a}}\left(\mathrm{CH}_{3}\right)$ & 2972 & 2941 & weak (32) & $33^{\circ}$ & $\perp$ & 2992 & $2948 / 2948 / 2949$ & $\mathrm{w} / \mathrm{m} / \mathrm{m}$ \\
\hline$v_{\mathrm{a}}\left(\mathrm{CH}_{3}\right)$ & 2935 & 2890 & weak (38) & $89^{\circ}$ & $\perp$ & 2956 & $2912 / 2912 / 2915$ & $\mathrm{w} / \mathrm{w} / \mathrm{w}$ \\
\hline$\delta_{\mathrm{s}}\left(\mathrm{CH}_{3}\right)$ & 1180 & 1182 & weak (28) & $56^{\circ}$ & $\perp$ & 1205 & $1185 / 1191 / 1198$ & $\mathrm{w} / \mathrm{m} / \mathrm{w}$ \\
\hline$v(\mathrm{C}-\mathrm{O})+\rho\left(\mathrm{CH}_{3}\right)$ & 1088 & 1077 & strong (263) & $12^{\circ}$ & $\perp$ & 1115 & $1077 / 1096 / 1107$ & vs \\
\hline $\mathrm{Si}-\mathrm{O}$ & 730 & 728 & weak (64) & & $\perp$ & 845 & 765/787/819 & $\mathrm{s}$ \\
\hline
\end{tabular}

${ }^{a}$ Intensities calculated from the cluster model are presented in parentheses and are reported in units of $\mathrm{km} / \mathrm{mol}$. Calculated intensity values cannot be compared qualitatively between the high and low frequency regions. The $\mathrm{Si}-\mathrm{O}$ mode at $728 \mathrm{~cm}^{-1}$ produces some displacements in the underlying Si atoms and prevent an accurate evaluation of the intensity. ${ }^{b}$ This refers to the angle the net dipole moment for a given mode makes relative to the surface normal. The angles were obtained from DFT calculations by summing the products of the atomic displacements and atomic charges. ${ }^{c}$ Orientation refers to the experimentally observed orientation of the modes through angle-resolved FTIR measurements. The symbol, $\perp$, means that the modes are oriented nearly perpendicular to the surface; since light-incidence angles of only 74 and $10^{\circ}$ off normal were used, the experimental results cannot give more precision in the orientation.

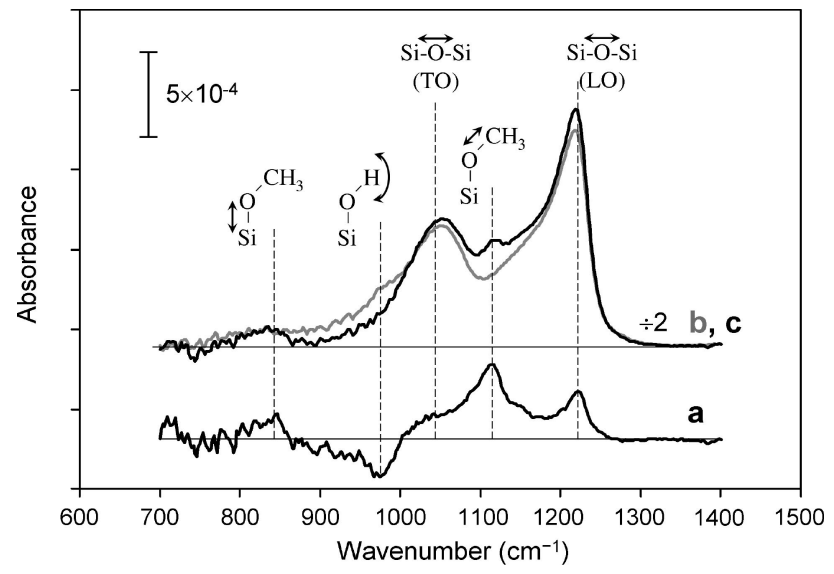

Figure 4. FTIR spectra of a $5-10 \AA$ thick oxide-terminated $n$-Si(111) surface immersed in neat anhydrous $\mathrm{CH}_{3} \mathrm{OH}$ (l) for $3 \mathrm{~h}$ at $65^{\circ} \mathrm{C}$. Spectrum a represents the $\mathrm{CH}_{3} \mathrm{OH}$-treated oxide surface referrenced to the initial oxide. Spectra $\mathrm{b}$ and $\mathrm{c}$ (divided by a factor of 2 for clarity) are the oxide surface (gray) and the $\mathrm{CH}_{3} \mathrm{OH}$-treated surface (black), respectively, both referenced relative to an oxide-free $\mathrm{H}-\mathrm{Si}(111)$ surface.

the sharp peak at $1220 \mathrm{~cm}^{-1}$ of Figure $4 \mathrm{a}$ can be assigned to increases in the asymmetric $\mathrm{Si}-\mathrm{O}-\mathrm{Si} \mathrm{TO}$ and $\mathrm{LO}$ stretching modes of the surface oxide layer, respectively. This increase in the TO and LO modes is either due to an increase in the oxide thickness, via continued oxidation, or to an increase in the structural order of the oxide, or both. In addition to the TO and LO modes, positive absorbance features associated with the complex $\mathrm{O}-\mathrm{C}$ mode at $1118 \mathrm{~cm}^{-1}$ and a $\mathrm{Si}-\mathrm{O}$ stretch around $845 \mathrm{~cm}^{-1}$ are observed, as well as a negative feature ascribable to a loss in the $\mathrm{SiO}-\mathrm{H}$ bending mode at $977 \mathrm{~cm}^{-1}$ (Figure 4a). Importantly, the complex $\mathrm{O}-\mathrm{C}$ and $\mathrm{Si}-\mathrm{O}$ stretching modes are blue-shifted by $30 \mathrm{~cm}^{-1}$ and over $100 \mathrm{~cm}^{-1}$ respectively on the oxide surface (Figure $4 \mathrm{a}$ ) relative to what is observed on the oxide-free $\mathrm{Si}-\mathrm{OCH}_{3}$ surface (Figure $2 \mathrm{~b}$ ). One $v_{\mathrm{s}}\left(\mathrm{CH}_{3}\right)$ and two $v_{\mathrm{a}}\left(\mathrm{CH}_{3}\right)$ modes (not shown) appear at 2854, 2956, and 2992 $\mathrm{cm}^{-1}$, respectively, and are roughly $20 \mathrm{~cm}^{-1}$ blue-shifted relative to those observed on the nominally oxide-free $\mathrm{Si}(111)$ surface (Figure 2b).

In order to eliminate spectral features due to changes in the thin surface oxide layer during the reaction with $\mathrm{CH}_{3} \mathrm{OH}$, the same reaction was carried out on $\mathrm{Si}(100)$ samples with a thermally generated $25-60 \AA$ thick oxide layer provided by the commercial vendor. Figure 5 displays the low frequency FTIR results obtained for the reaction of this oxide-terminated $\mathrm{Si}(100)$ surface with neat anhydrous $\mathrm{CH}_{3} \mathrm{OH}$ (l) for $3 \mathrm{~h}$ at 65 ${ }^{\circ} \mathrm{C}$. For comparison, the spectrum of Figure $4 \mathrm{a}$ (thin wet-

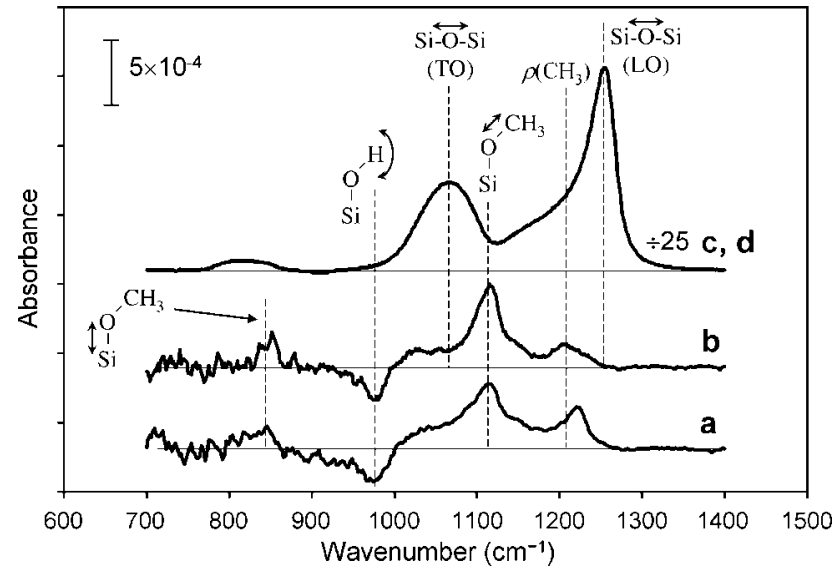

Figure 5. FTIR spectra of a $25-60 \AA$ thick oxide-terminated $\mathrm{Si}(100)$ surface immersed in neat anhydrous $\mathrm{CH}_{3} \mathrm{OH}$ (l) for $3 \mathrm{~h}$ at 65 ${ }^{\circ} \mathrm{C}$. Spectrum a is reproduced from Figure 4a (thin chemical oxide). Spectra b-d represent the reaction on the $25-60 \AA$ A thick oxide surface. Spectrum b represents the $\mathrm{CH}_{3} \mathrm{OH}$-treated oxide surface referenced to the initial oxide. Spectra $\mathrm{c}$ and $\mathrm{d}$ are the oxide (gray) and the $\mathrm{CH}_{3} \mathrm{OH}$ exposed oxide (black) surfaces (referenced relative to an oxide-free $\mathrm{H}-\mathrm{Si}(100)$ surface). Spectrum $\mathrm{b}$ is not complicated by changes in the asymmetric $\mathrm{Si}-\mathrm{O}-\mathrm{Si} \mathrm{TO}$ or $\mathrm{LO}$ modes, which allows the $\mathrm{Si}-\mathrm{OCH}_{3}$ umbrella mode, $\rho\left(\mathrm{CH}_{3}\right)$, to be observed at $1205 \mathrm{~cm}^{-1}$.

chemical oxide) is reproduced as Figure 5a. Spectrum Figure $5 \mathrm{~b}$ is the absorbance spectrum generated by referencing the $\mathrm{CH}_{3} \mathrm{OH}$-treated $25-60 \AA$ thick $\mathrm{Si}(100)$ oxide surface relative to the initial oxide. Spectra $\mathrm{c}$ and $\mathrm{d}$ in Figure 5 are the initial 25-60 $\AA$ thick oxide surface (gray), and the $\mathrm{CH}_{3} \mathrm{OH}$-exposed oxide surface (black), respectively, each referenced relative to the oxide-free $\mathrm{H}-\mathrm{Si}(100)$ surface that was created at the end of the experiment. The significantly thicker oxide layer produces asymmetric $\mathrm{Si}-\mathrm{O}-\mathrm{Si}$ TO and LO modes at 1050 and 1260 $\mathrm{cm}^{-1}$, respectively, that are not only much stronger in intensity (requiring division of the spectra by 25 for clarity) but the LO mode is significantly blue-shifted in frequency compared to the thinner oxide. ${ }^{71}$ The weaker mode at $\sim 820 \mathrm{~cm}^{-1}$ on spectra $5 \mathrm{c}$ and $5 \mathrm{~d}$ represents the unresolved $\mathrm{TO}$ and $\mathrm{LO}$ pair of the symmetric $\mathrm{Si}-\mathrm{O}-\mathrm{Si}$ stretching modes. ${ }^{73}$ The absence of modes at 1050 and $1260 \mathrm{~cm}^{-1}$ on spectrum $5 \mathrm{~b}$ demonstrates that no changes in the oxide layer occurred during the reaction with $\mathrm{CH}_{3} \mathrm{OH}$, and thus the umbrella mode, $\rho\left(\mathrm{CH}_{3}\right)$, of the methoxyl group is now apparent at $\sim 1205 \mathrm{~cm}^{-1}$. Comparison of the spectra obtained on oxides of different thicknesses (Figure 5, spectra $a$ and b) shows that, despite the spectral changes associated with the TO and LO modes of the thinner oxide, the peaks ascribable to the complex $\mathrm{O}-\mathrm{C}$ mode, $\mathrm{SiO}-\mathrm{H}$ bending mode, and the $\mathrm{Si}-\mathrm{O}$ stretch do not change in frequency. 


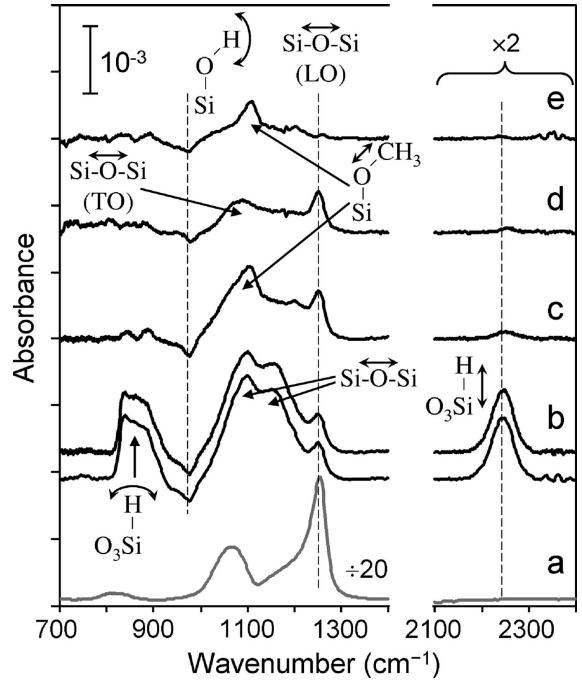

Figure 6. FTIR spectra of a hydrogen-terminated oxide surface after various reactions. Figure 6 a presents the initial $25-60 \AA$ A thick oxidecovered $\mathrm{Si}(100)$ surface relative to an oxide-free $\mathrm{H}-\mathrm{Si}(100)$ surface. Spectrum $b$ presents the oxide surface after exposure to the TCS solution before and after sonication. Subsequent reaction of the surface with $65{ }^{\circ} \mathrm{C} \mathrm{CH}_{3} \mathrm{OH}$ for $10 \mathrm{~min}$ (spectrum c) significantly reduces the TCSformed $\mathrm{O}_{3} \mathrm{Si}-\mathrm{H}$ and $\mathrm{Si}-\mathrm{O}-\mathrm{Si}$ modes and forms $\mathrm{O}_{3} \mathrm{Si}-\mathrm{OCH}_{3}$ species. Selective exchange of $\mathrm{Si}-\mathrm{OCH}_{3}$ groups with $\mathrm{Si}-\mathrm{OH}$ groups occurs after exposure of the surface to a 5 min SC2 solution (spectrum d). Spectrum e represents the $\mathrm{CH}_{3} \mathrm{OH}$-reacted surface referenced relative to the final SC2-cleaned surface (see text for more details). All spectra within the region of $2100-2400 \mathrm{~cm}^{-1}$ are multiplied by a factor of 2 .

\section{Reaction of Hydrogen-Terminated Oxide Surfaces} with Methanol. Despite the occurrence of the $\mathrm{SiO}_{2}$ on the roomtemperature-reacted $\mathrm{Si}-\mathrm{OCH}_{3}$ surface (Figure 2a), no evidence for the presence of $\mathrm{O}_{x} \mathrm{Si}-\mathrm{H}$ species are observed. Such $\mathrm{O}_{x} \mathrm{Si}-\mathrm{H}$ species could be formed transiently, however, provided a fast reaction of these sites with $\mathrm{CH}_{3} \mathrm{OH}$ ensues. In order to investigate this possibility, the reaction of hydrogen-terminated oxide surfaces with $\mathrm{CH}_{3} \mathrm{OH}$ (1) was studied. Such surfaces were generated by immersing an oxide-terminated sample in a 35 ${ }^{\circ} \mathrm{C}$ solution of trichlorosilane, $\mathrm{Cl}_{3} \mathrm{Si}-\mathrm{H}$ (TCS, 99\%), in anhydrous toluene ( $\sim 15 \mathrm{mM}$, or $40-60 \mu \mathrm{L}$ TCS in $30 \mathrm{~mL}$ toluene) for $6 \mathrm{~h}$. A simplified reaction can be written as follows, where the subscript $\mathrm{s}$ represents the surface bound species. ${ }^{87}$

$$
\begin{gathered}
\mathrm{Cl}_{3} \mathrm{SiH}+3 \mathrm{H}_{2} \mathrm{O} \rightarrow(\mathrm{HO})_{3} \mathrm{SiH}+3 \mathrm{HCl} \\
n \mathrm{Si}_{\mathrm{s}} \mathrm{OH}+(\mathrm{HO})_{3} \mathrm{SiH} \rightarrow\left(\mathrm{Si}_{\mathrm{s}} \mathrm{O}\right)_{n}(\mathrm{HO})_{(3-n)} \mathrm{SiH}+n \mathrm{H}_{2} \mathrm{O}
\end{gathered}
$$

In the first step, the TCS molecule undergoes hydrolysis with $\mathrm{H}_{2} \mathrm{O}$ molecules that are either in solution or physisorbed to the surface of the oxide layer. In the second step, the hydrolyzed TCS molecule undergoes some number, $(1 \leq n \leq 3)$, of condensation reactions with a corresponding number of $\mathrm{Si}-\mathrm{OH}$ surface groups; the remaining hydrolyzed sites of the TCS molecule either remain as $\mathrm{Si}-\mathrm{OH}$ groups or they may undergo condensation with neighboring, or incoming, hydrolyzed TCS molecules.

Figure 6 displays the low frequency FTIR spectra for hydrogen-terminated oxide surfaces with methanol. In Figure $6 \mathrm{a}$, the spectrum of the $25-60 \AA$ thick oxide-terminated $\mathrm{Si}(100)$ wafer, which was the starting surface for subsequent chemistry, is displayed relative to the oxide-free hydrogen-terminated $\mathrm{Si}(100)$ surface formed upon completion of the experiment; this spectrum (divided by 20) is included to show the frequencies of the $\mathrm{Si}-\mathrm{O}-\mathrm{Si} \mathrm{LO}\left(1260 \mathrm{~cm}^{-1}\right)$ and TO $\left(1050 \mathrm{~cm}^{-1}\right)$ modes for comparison. The lower spectrum of Figure $6 \mathrm{~b}$ displays the absorbance spectrum after immersion of the initial oxide in a $35{ }^{\circ} \mathrm{C}$ solution of TCS in toluene for $6 \mathrm{~h}$ in the dark; this spectrum is referenced relative to the initial oxide surface. The positive absorbance modes around 850 and $2245 \mathrm{~cm}^{-1}$ correspond to the $\mathrm{Si}-\mathrm{H}$ bending and stretching modes, respectively, for the $\mathrm{O}_{3} \mathrm{Si}-\mathrm{H}$ species; for all spectra, absorbance values between 2100 and $2400 \mathrm{~cm}^{-1}$ are multiplied by 2 for clarity. The $2245 \mathrm{~cm}^{-1} \mathrm{O}_{3} \mathrm{Si}-\mathrm{H}$ stretching mode displays an area of $\sim 0.027 \mathrm{AU} \mathrm{cm}^{-1}$. Assuming the $\mathrm{O}_{3} \mathrm{Si}-\mathrm{H}$ and $(111) \mathrm{Si}-\mathrm{H}$ species have similar oscillator strengths, the (111) $\mathrm{Si}-\mathrm{H}$ area of $\sim 0.014 \mathrm{AU} \mathrm{cm}^{-1}$ implies that the TCS film is roughly two monolayers thick. The negative feature at $977 \mathrm{~cm}^{-1}$ is due to the loss of surface-atop $\mathrm{Si}-\mathrm{OH}$ species from reaction with hydrolyzed TCS molecules. ${ }^{82}$ The positive mode at $1260 \mathrm{~cm}^{-1}$ corresponds to the generation of $\mathrm{Si}-\mathrm{O}-\mathrm{Si}$ species that are coupled to the $\mathrm{Si}-\mathrm{O}-\mathrm{Si} \mathrm{LO}$ mode of the surface oxide (c.f. Figure 6a). The positive modes between 1050 and $1200 \mathrm{~cm}^{-1}$ correspond to new $\mathrm{Si}-\mathrm{O}-\mathrm{Si}$ modes that are isolated (not coupled) to the bulk LO mode. The upper spectrum of Figure $6 \mathrm{~b}$ was obtained after the surface was sonicated for $10 \mathrm{~min}$ in toluene to remove any physisorbed $\mathrm{Si}-\mathrm{O}-\mathrm{Si}$ oligomers deposited from solution-phase condensation of TCS molecules. ${ }^{81}$ Since there is no statistical difference in areas of these two spectra, we conclude that negligible amounts of condensation products were physisorbed to this particular sample; thus, all observed $\mathrm{Si}-\mathrm{O}-\mathrm{Si}$ modes are assumed to be directly bound to the surface in some form.

Figure $6 \mathrm{c}$ displays the absorbance spectrum of the $\mathrm{H}$ terminated oxide surface after a 10 min reaction in $65{ }^{\circ} \mathrm{C}$ $\mathrm{CH}_{3} \mathrm{OH}$ (l) in the dark (referenced relative to the initial oxide surface). The stretching and bending modes for $\mathrm{O}_{3} \mathrm{Si}-\mathrm{H}$ species almost completely disappear with only $10 \pm 4 \%$ of the initial $\mathrm{O}_{3} \mathrm{Si}-\mathrm{H}$ groups remaining. This is in stark contrast to the $\approx 90 \%$ $\mathrm{Si}-\mathrm{H}$ remaining on the $\mathrm{H}-\mathrm{Si}(111)$ surface under the same reaction conditions (Figure 3a, Table 1). In addition to the loss of the $\mathrm{O}_{3} \mathrm{Si}-\mathrm{H}$ modes, a significant proportion of the uncoupled $\mathrm{Si}-\mathrm{O}-\mathrm{Si}$ modes (between 1050 and $1200 \mathrm{~cm}^{-1}$ ) have disappeared while the $\mathrm{Si}-\mathrm{O}-\mathrm{Si}$ species that coupled to the $\mathrm{Si}-\mathrm{O}-\mathrm{Si}$ LO mode $\left(\sim 1260 \mathrm{~cm}^{-1}\right)$ remain relatively unchanged. The significant loss of the uncoupled $\mathrm{Si}-\mathrm{O}-\mathrm{Si}$ modes (1050-1200 $\mathrm{cm}^{-1}$ ) is in stark contrast to the negligible loss of oxide-layercoupled $\mathrm{Si}-\mathrm{O}-\mathrm{Si}$ modes $\left(1250 \mathrm{~cm}^{-1}\right)$. This indicates a surprising difference in the reactivity of these two types of $\mathrm{Si}-\mathrm{O}-\mathrm{Si}$ species. As evidence for the formation of $\mathrm{O}_{x} \mathrm{Si}-\mathrm{OCH}_{3}$ groups, small positive modes at 1115 and $1205 \mathrm{~cm}^{-1}$ are assigned to the complex $\mathrm{O}-\mathrm{C}$ and $\mathrm{CH}_{3}$ umbrella modes.

Figure $6 \mathrm{~d}$ displays the spectrum obtained after dipping the $\mathrm{CH}_{3} \mathrm{OH}$-exposed surface into an $\mathrm{SC} 2$ solution for $5 \mathrm{~min}$ (the initial oxide surface is used as a reference). The acidic SC2 solution is assumed to only hydrolyze the atop $\mathrm{Si}-\mathrm{OCH}_{3}$ groups into $\mathrm{Si}-\mathrm{OH}$ groups while not affecting the $\mathrm{Si}-\mathrm{O}-\mathrm{Si}$ groups. Accordingly, Figure 6d demonstrates that the complex O-C $\left(1115 \mathrm{~cm}^{-1}\right)$ and umbrella $\mathrm{CH}_{3}\left(1205 \mathrm{~cm}^{-1}\right)$ modes, that were present in Figure 6c, disappear. The frequencies of the remaining $\mathrm{Si}-\mathrm{O}-\mathrm{Si}$ modes $\left(1050\right.$ and $1260 \mathrm{~cm}^{-1}$ ) compare well to the $\mathrm{Si}-\mathrm{O}-\mathrm{Si} \mathrm{LO}$ and TO modes of Figure 6a. Figure 6e presents the spectrum of the $\mathrm{CH}_{3} \mathrm{OH}$-reacted surface relative to the surface generated after the final SC2 clean. The positive absorbance features thus represent the chemical species removed during the SC2 cleaning. The negative mode at $977 \mathrm{~cm}^{-1}$ means that $\mathrm{Si}-\mathrm{OH}$ sites are formed upon the loss of $\mathrm{Si}-\mathrm{OCH}_{3}$ sites. 

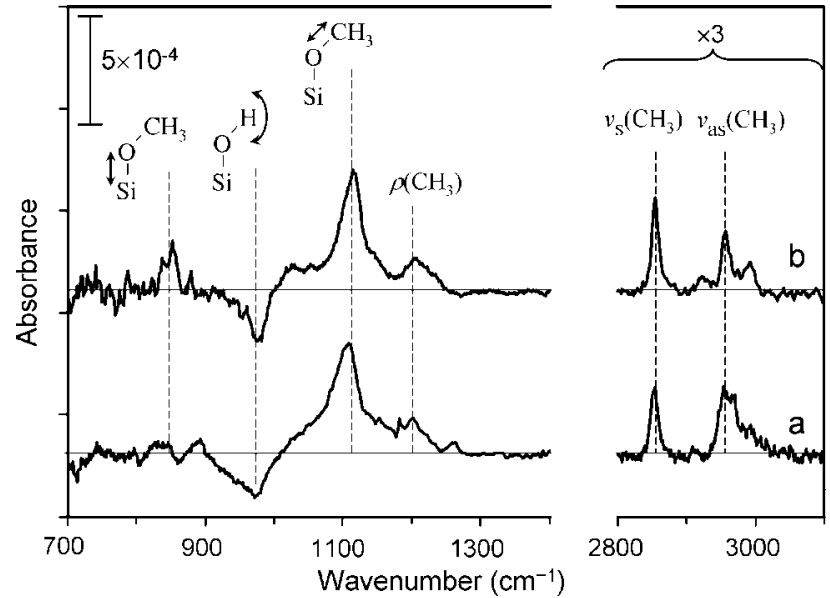

Figure 7. FTIR spectra of (a) a hydrogen-terminated oxide $\left(\mathrm{O}_{3} \mathrm{Si}-\mathrm{H}\right)$ sample (from Figure 6e) and (b) a hydroxy-terminated oxide $\left(\mathrm{O}_{3} \mathrm{Si}-\mathrm{OH}\right)$ sample (from Figure 5b) after reaction in $65^{\circ} \mathrm{C} \mathrm{CH}_{3} \mathrm{OH}$. The $\mathrm{C}-\mathrm{H}$ stretching region is also included. The similar spectral features and intensities indicate that the resulting surfaces are very similar despite the difference in the initial surface chemistry.

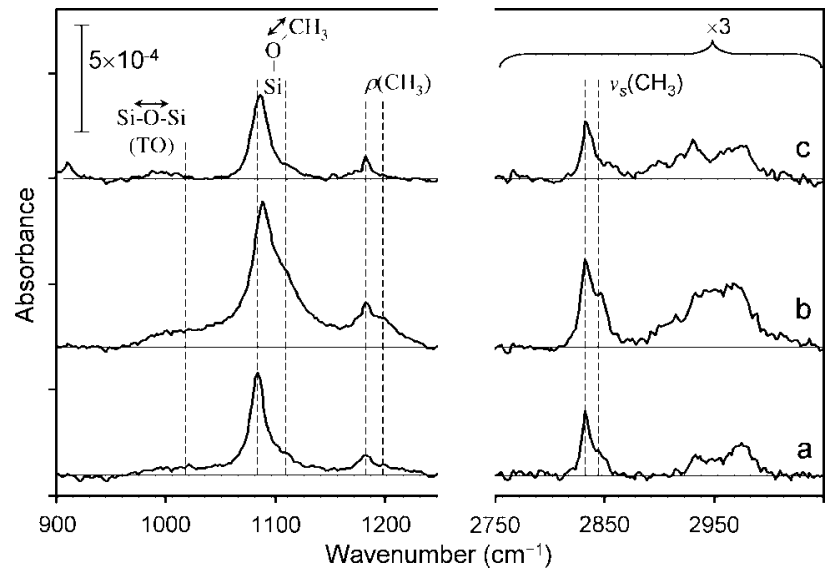

Figure 8. FTIR spectra of a deliberately oxidized methoxy-terminated sample. An atomically smooth hydrogen-terminated $n$-Si(111) sample was sequentially exposed to (a) neat anhydrous methanol for $3 \mathrm{~h}$ at 65 ${ }^{\circ} \mathrm{C}$, (b) dark air for $14 \mathrm{~h}$, followed by $10 \mathrm{~h}$ in $65^{\circ} \mathrm{C}$ methanol, and finally (c) $37 \mathrm{~s}$ in $48 \% \mathrm{HF}(\mathrm{aq})$. Correlated with the appearance of oxidation $(\mathrm{Si}-\mathrm{O}-\mathrm{Si} \mathrm{TO})$ are blue-shifted components of the complex $\mathrm{O}-\mathrm{C}, \rho\left(\mathrm{CH}_{3}\right)$, and $v_{\mathrm{s}}\left(\mathrm{CH}_{3}\right)$ modes (spectrum b). The $\mathrm{Si}-\mathrm{O}-\mathrm{Si} \mathrm{TO}$ and blue-shifted components are both significantly reduced upon exposure to $48 \% \mathrm{HF}(\mathrm{aq})$ (spectrum c), whereas the non-blue-shifted components are relatively unaffected. All spectra are referenced relative to the initial atomically smooth $\mathrm{H}-\mathrm{Si}(111)$.

The spectrum is very similar to that obtained after reacting the bare 25-60 Ang $\mathrm{Si}(100)$ oxide surface with $\mathrm{CH}_{3} \mathrm{OH}$ for $3 \mathrm{~h}$ (Figure 5b).

The $\mathrm{CH}_{3} \mathrm{OH}$-reacted hydrogen-terminated oxide surface (of Figure 6e) and the $\mathrm{CH}_{3} \mathrm{OH}$-reacted hydroxy-terminated oxide surface (of Figure 5b) are reproduced in Figure 7 along with the $\mathrm{C}-\mathrm{H}$ stretching region for comparison. The spectral features and intensities of both spectra are very similar (including the $v_{\mathrm{s}}\left(\mathrm{CH}_{3}\right)$ mode at $\left.2854 \mathrm{~cm}^{-1}\right)$ despite the difference in the initial surface chemistry. The spectra in Figures 4-7 and the data summarized in Table 2 demonstrate that the modes associated with surface-bound $\mathrm{O}_{x} \mathrm{Si}-\mathrm{OCH}_{3}$ group are blue-shifted on oxidized silicon surfaces relative to those on oxide-free $\mathrm{Si}(111)$ surfaces.

D. Deliberate Oxidation of Methoxylated Surfaces. An oxide-free methoxylated surface was deliberately oxidized in air to observe any shifts in the $\mathrm{Si}-\mathrm{OCH}_{3}$ vibration modes. The

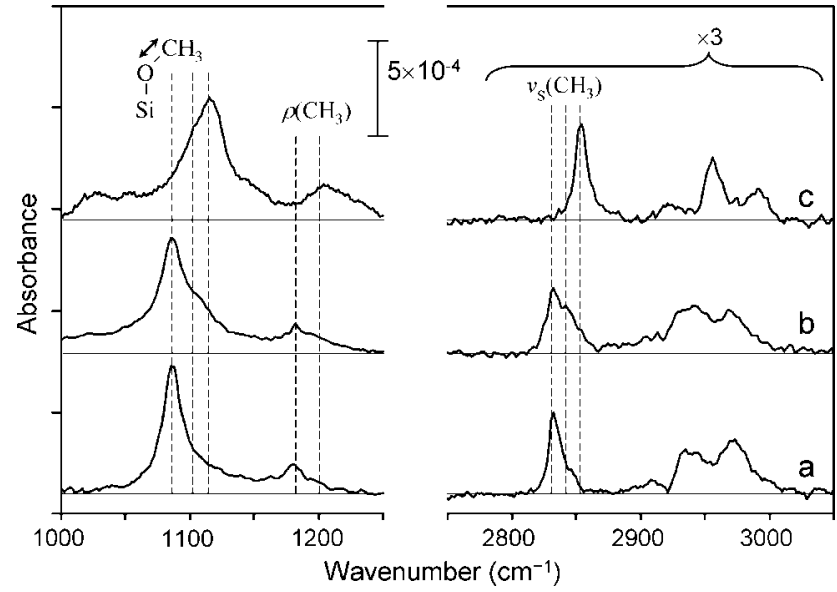

Figure 9. Comparison of spectral features for different $\mathrm{CH}_{3} \mathrm{O}$ terminated surfaces: (a) a flat $\mathrm{H}-\mathrm{Si}(111)$ exposed to $65^{\circ} \mathrm{C} \mathrm{CH}_{3} \mathrm{OH}$ (1) for $3 \mathrm{~h}$, (b) a flat $\mathrm{H}-\mathrm{Si}(111)$ exposed to room temperature $\mathrm{CH}_{3} \mathrm{OH}$ (1) for 6 days, and (c) a $25-60 \AA$ thick oxide surface exposed to $65^{\circ} \mathrm{C}$ $\mathrm{CH}_{3} \mathrm{OH}$ (l) for $3 \mathrm{~h}$. The sharp modes of the virtually oxide free surface of spectrum a are the lowest in frequency. Significant blue-shifted components of the same modes are observed for the oxide-containing room-temperature reacted surface (b). The modes are the most blueshifted on an oxide surface (c).

spectrum of Figure $8 \mathrm{a}$ demonstrates that the initial $\mathrm{Si}-\mathrm{OCH}_{3}$ surface, formed after immersion in $65^{\circ} \mathrm{C}$ methanol is free of significant $\mathrm{SiO}_{2}{ }^{83}$ The surface was subsequently oxidized through a $14 \mathrm{~h}$ exposure to laboratory air in the dark followed by a $10 \mathrm{~h}$ reaction in $65^{\circ} \mathrm{C}$ methanol (Figure $8 \mathrm{~b}$ ). Subsurface oxidation is verified by the appearance of a $\mathrm{Si}-\mathrm{O}-\mathrm{Si} \mathrm{TO}$ mode $\left(\sim 1020 \mathrm{~cm}^{-1}\right)$. In addition, observable blue-shifted components of the complex $\mathrm{O}-\mathrm{C}, \mathrm{CH}_{3}$ umbrella, and $v_{\mathrm{s}}\left(\mathrm{CH}_{3}\right)$ modes of $\mathrm{Si}-\mathrm{OCH}_{3}$ groups also appear. These blue-shifted components, as well as the $\mathrm{Si}-\mathrm{O}-\mathrm{Si} \mathrm{TO}$ mode, are significantly reduced upon the subsequent dip of the surface in $27 \mathrm{M} \mathrm{HF}(\mathrm{aq})$ for $37 \mathrm{~s}$ (Figure $8 \mathrm{c}$ ). These results demonstrate that the $\mathrm{Si}-\mathrm{O}-\mathrm{Si}$ oxidation and blue-shifted $\mathrm{Si}-\mathrm{OCH}_{3}$ modes are strongly correlated. (See the Supporting Information section for more analysis.) These results also demonstrate that non-blue-shifted (subsurface-oxide-free) $\mathrm{Si}-\mathrm{OCH}_{3}$ groups are more chemically inert to $27 \mathrm{M} \mathrm{HF}(\mathrm{aq})$ than the blue-shifted $\mathrm{Si}-\mathrm{OCH}_{3}$ groups, which are presumably located above regions of subsurface oxide that are undercut and removed by the aqueous HF. Consistently, the appearance of the mode at $911 \mathrm{~cm}^{-1}$, which is assigned to a dihydride $\left(\mathrm{SiH}_{2}\right)$ mode, is evidence for surface roughening due to the removal of oxidation by $\mathrm{HF}(\mathrm{aq})$.

The assignment of blue-shifted modes to $\mathrm{O}_{\mathrm{x}} \mathrm{Si}-\mathrm{OCH}_{3}$ species is highlighted in Figure 9, where the spectra from several different surfaces are plotted together for comparison. Figure $9 \mathrm{a}$ is a spectrum of a flat $\mathrm{H}-\mathrm{Si}(111)$ exposed to $65^{\circ} \mathrm{C} \mathrm{CH}_{3} \mathrm{OH}$ for $3 \mathrm{~h}$ in the dark, and there are no detectable $\mathrm{Si}-\mathrm{O}-\mathrm{Si}$ modes with only negligible components of the blue-shifted complex $\mathrm{O}-\mathrm{C}$, umbrella $\mathrm{CH}_{3}$, and $v_{\mathrm{s}}\left(\mathrm{CH}_{3}\right)$ stretching modes; this spectrum thus presents one of the least oxidized samples. The positions of the oxide-free modes at 1088, 1180, and $2833 \mathrm{~cm}^{-1}$ for the complex $\mathrm{O}-\mathrm{C}$, umbrella $\mathrm{CH}_{3}$, and $v_{\mathrm{s}}\left(\mathrm{CH}_{3}\right)$ stretching modes, respectively, are indicated by broken lines. Figure $9 \mathrm{~b}$ represents a flat $\mathrm{H}-\mathrm{Si}(111)$ surface exposed to room temperature $\mathrm{CH}_{3} \mathrm{OH}$ (1) for 6 days in the dark. The blue-shifted modes are indicated by broken lines at 1105,1190 , and $2843 \mathrm{~cm}^{-1}$ for the complex $\mathrm{O}-\mathrm{C}$, umbrella $\mathrm{CH}_{3}$, and $v_{\mathrm{s}}\left(\mathrm{CH}_{3}\right)$ stretching modes, respectively. This sample also displays a visible $\mathrm{Si}-\mathrm{O}-\mathrm{Si} \mathrm{TO}$ mode $\left(1050 \mathrm{~cm}^{-1}\right)$, which is illuminated by the straight line drawn near the baseline. Figure 9c (also Figure 5b) presents 
the spectrum for the $25-60 \AA$ thick oxide-terminated $\mathrm{Si}(100)$ surface exposed to $\mathrm{CH}_{3} \mathrm{OH}$ at $65^{\circ} \mathrm{C}$ for $3 \mathrm{~h}$ in the dark. This spectrum demonstrates that the complex $\mathrm{O}-\mathrm{C}$, umbrella $\mathrm{CH}_{3}$, and $v_{\mathrm{s}}\left(\mathrm{CH}_{3}\right)$ modes, indicated by broken lines at 1115,1205 , and $2854 \mathrm{~cm}^{-1}$, respectively, are the most blue-shifted on a fully oxidized surface.

E. Theoretical Calculations. Results from the DFT calculations are displayed in Table 2. Consistent with the experimental results, DFT calculations demonstrate that atop $\mathrm{Si}-\mathrm{OCH}_{3}$ vibrational modes are blue-shifted by an amount related to the number of $\mathrm{O}$ atoms in the back bonds. The experimentally observed stretching frequencies are also presented in Table 2 for the nominally oxide-free $\left(\mathrm{Si}_{3} \mathrm{Si}-\mathrm{OCH}_{3}\right)$ surface as well as for the 25-60 $\AA$ thick-oxide-terminated $\left(\mathrm{O}_{3} \mathrm{Si}-\mathrm{OCH}_{3}\right)$ surface. Interestingly, the amount of the shift is proportional to the closeness of the particular vibrational mode to the subsurface oxygen atoms. For example, the experimentally observed shift in the $\mathrm{Si}-\mathrm{O}$ mode from the unoxidized surface to the oxideterminated surface is $115 \mathrm{~cm}^{-1}$, and a shift of $85 \mathrm{~cm}^{-1}$ is predicted by DFT calculations. For the complex $\mathrm{O}-\mathrm{C}$ mode, an experimentally observed (DFT-calculated) shift of $27 \mathrm{~cm}^{-1}$ is observed $\left(22 \mathrm{~cm}^{-1}\right.$ predicted). For the $\mathrm{C}-\mathrm{H}$ stretching modes, an experimentally observed shift of $\sim 20 \mathrm{~cm}^{-1}$ for each mode is similar to the results predicted by DFT calculations. These trends in blue-shifting are not surprising because the presence of the oxygen atoms in the back bonds will likely have a stronger charge polarizing effect on the $\mathrm{Si}-\mathrm{O}$ bond than on the more physically remote $\mathrm{O}-\mathrm{C}$ and $\mathrm{C}-\mathrm{H}$ bonds.

\section{Discussion}

A. Methoxy-Terminated Silicon. The spectra presented in this work highlight several important aspects of silicon surface chemistry. First, hydrogen-terminated Si(111) surfaces can be functionalized via a wet-chemical technique up to $\sim 30 \%$ of a monolayer with direct $\mathrm{Si}-\mathrm{O}$ linkages without the formation of any detectable $\mathrm{SiO}_{2}$ (Figures $2 \mathrm{~b}$ and 3 ). This is important because high-temperature gas phase reactions of $\mathrm{O}_{2}$ on $\mathrm{H}-\mathrm{Si}(111)$ surfaces or of $\mathrm{H}_{2} \mathrm{O}$ deposition, and subsequent annealing of, reconstructed $\mathrm{Si}(100)$ surfaces demonstrate a high preference of subsurface $\mathrm{Si}-\mathrm{Si}$ back-bonds to oxidize ${ }^{84}$ via an oxygen insertion mechanism. ${ }^{76,85,86}$ Thus, there is concern that atop $\mathrm{Si}-\mathrm{O}$ linkages will be unstable toward decomposition via oxygen diffusion into the back bonds and result in electrically defective subsurface oxidation. Although this sort of decomposition has been demonstrated at elevated temperatures, ${ }^{71,87}$ this work shows that a suitable wet-chemical technique can produce surface atop $\mathrm{Si}-\mathrm{O}$ linkages without subsurface oxidation. Consistently, electrically passive methoxy-terminated Si surfaces, produced through a different wet-chemical technique, have notably long photoinjected charge carrier lifetimes under nitrogen ${ }^{3,88}$ and good current-voltage behavior when implemented as silicon photoelectrodes. ${ }^{22,46,89}$ Thus, the formation of the $\mathrm{Si}-\mathrm{O}$ linkages can, in principle, provide an easy functionalization route on $\mathrm{Si}(111)$-oriented wafers that is not complicated by issues of catalysis ${ }^{55}$ or the necessity of multistep reactions while nevertheless maintaining good surface electrical properties. Interestingly, the same chemical treatment of $65^{\circ} \mathrm{C}$ $\mathrm{CH}_{3} \mathrm{OH}$ on $\mathrm{Si}(100)$ wafers consistently led to significant subsurface oxidation. These results are consistent with the higher oxidation kinetics measured for the $\mathrm{Si}(100)$ surface relative to the $\mathrm{Si}(111)$ surface ${ }^{76,86}$ These results provide strong motivation for the use of $\mathrm{Si}(111)$ surfaces over $\mathrm{Si}(100)$ surface for those electronic devices where atomically smooth, more-controllable, and less-reactive surfaces are needed.

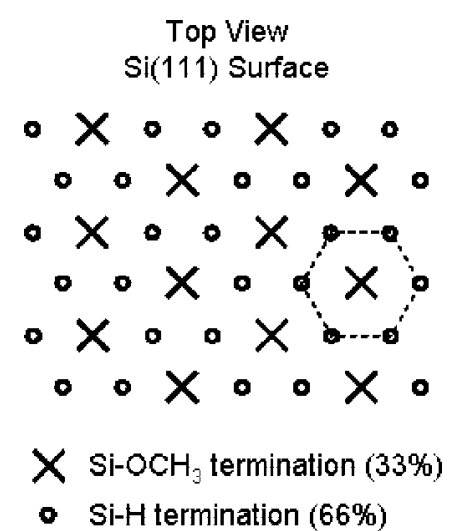

Figure 10. Top-view schematic of the silicon (111) surface with a periodic coverage of $66 \% \mathrm{Si}-\mathrm{H}$ (circles) and $33 \% \mathrm{Si}-\mathrm{OCH}_{3}$ (crosses). The broken-line hexagon shows that the saturation coverage (Table 1) can be represented as a $\mathrm{Si}-\mathrm{OCH}_{3}$ moiety surrounded entirely by nearest-neighbor $\mathrm{Si}-\mathrm{H}$ groups. Nearest neighbor sites could be sterically inhibited from reaction by the $360^{\circ}$ thermal rotation of the methyl group about the $\mathrm{Si}-\mathrm{O}$ bond.

The saturation coverage of methoxyl species at $\sim 30 \%$ of a monolayer is of particular interest. This coverage of $\mathrm{Si}-\mathrm{OCH}_{3}$ sites is close to a $33 \%$ coverage, which can be envisioned as a periodic array of $\mathrm{Si}-\mathrm{OCH}_{3}$ sites (crosses) surrounded by six nearest neighbor $\mathrm{Si}-\mathrm{H}$ sites (circles) (Figure 10). Such a geometry could be achieved through steric inhibition of nearest neighbor $\mathrm{Si}-\mathrm{H}$ groups by the thermal rotation of the $-\mathrm{CH}_{3}$ group about the $\mathrm{Si}-\mathrm{O}$ bond. A long-range periodicity, such as that depicted in Figure 10, most likely cannot be achieved on real surfaces due to the putative random surface reaction, ${ }^{90}$ but local $\mathrm{Si}-\mathrm{OCH}_{3}$ sites on a real surface may be surrounded by approximately $6 \mathrm{Si}-\mathrm{H}$ groups.

The experimentally observed limiting coverage of $\sim 30 \%$ for the $\mathrm{Si}-\mathrm{OCH}_{3}$ sites is interesting on another front because it contrasts with theoretical modeling, which predicts that the lowest surface strain is obtained for $100 \%$ coverage of methoxyl species. ${ }^{91}$ The low strain at $100 \%$ coverage is due to the Coulombic attraction between neighboring $\mathrm{Si}-\mathrm{OCH}_{3}$ groups. This modeling did not, however, take into consideration the steric or energetic limitations of the transition state for the reaction of methanol on $\mathrm{H}-\mathrm{Si}(111)$. Thus, while $100 \%$ coverage of the surface by $\mathrm{Si}-\mathrm{OCH}_{3}$ sites may exhibit less total strain than the $30 \%$ coverage observed in this work, it appears to be inaccessible, at least via a $65{ }^{\circ} \mathrm{C}$ reaction with neat anhydrous methanol, possibly due to steric restrictions of the transition state.

B. Mechanistic Remarks. 1. Hydrogen-Terminated Si(111) Surfaces. Because virtually oxide-free methoxylated surfaces up to $\sim 30 \%$ of a monolayer can be prepared, the formation of subsurface $\mathrm{Si}-\mathrm{O}-\mathrm{Si}$ modes is not inherent to the reaction with methanol. Specifically, one could envision reaction products being $\mathrm{Si}_{2}(\mathrm{Si}-\mathrm{O}) \mathrm{Si}-\mathrm{CH}_{3}$ and $\mathrm{H}_{2}(\mathrm{~g})$, where the oxygen atom from the methanol molecule ends up in one of the three $\mathrm{Si}-\mathrm{Si}$ back bonds, leaving an atop $\mathrm{Si}-\mathrm{CH}_{3}$ group. In addition to the absence of $\mathrm{Si}-\mathrm{O}-\mathrm{Si}$ modes on the $65{ }^{\circ} \mathrm{C}$ reaction with $\mathrm{H}-\mathrm{Si}(111)$ surfaces, no evidence for $\mathrm{Si}-\mathrm{CH}_{3}$ modes has been observed. $\mathrm{Si}-\mathrm{CH}_{3}$ surfaces has been studied in great detail using FTIR, ${ }^{11,109,100}$ and no peaks in the region of $\mathrm{Si}-\mathrm{CH}_{3}$ umbrella distortion $\left(757 \mathrm{~cm}^{-1}\right)$ or the $\mathrm{Si}-\mathrm{CH}_{3}$ rocking mode $\left(1257 \mathrm{~cm}^{-1}\right)$ have been observed out of the noise in this study. Such a surface reaction on $\mathrm{Si}(111)$ surfaces thus cannot occur with a significant contribution to the total surface coverage under these conditions.

2. Hydroxy-Terminated Oxide Surfaces. Several reaction mechanisms can be proposed on the basis of the FTIR data 


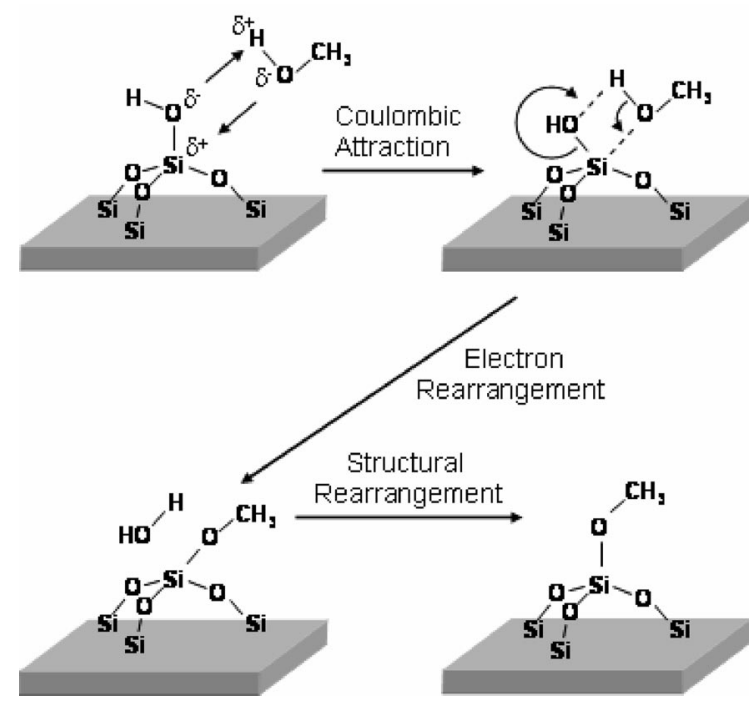

Figure 11. Possible reaction mechanism for the methoxylation of hydroxy-terminated oxide surface sites.

presented in this work. Figure 11 presents a possible reaction mechanism for the methoxylation of hydroxy-terminated surface sites on $\mathrm{SiO}_{2}$ oxide layer. Hydrogen bonding and Coulombic attraction bring the methanol molecule close to the surface hydroxyl $(\mathrm{Si}-\mathrm{OH})$ site such that it forms a four-memberedring transition state as depicted. This transition state involves a pentavalent coordinate geometry for silicon. Although pentaand hexa-coordinated silicon atoms occur for free molecules in solution, ${ }^{92}$ such geometries have only been assumed for silicon atoms bound in a surface lattice..$^{51,62,93}$ This transition state, however, is the lowest in energy of DFT calculations ${ }^{94}$ and is supported by FTIR measurements of isotopically labeled $\mathrm{CH}_{3} \mathrm{OH}$ molecules exposed to a $\mathrm{SiO}_{2}$ surface. ${ }^{95}$ From the putative transition state (Figure 11), electronic and structural rearrangements result in the formation of the methoxylated surface and the release of a water molecule. Despite the hydrophilic nature of the oxide surface, preferential adsorption of $\mathrm{CH}_{3} \mathrm{OH}$ over $\mathrm{H}_{2} \mathrm{O}$ has been observed for surface energy reasons. Thus, despite the release of $\mathrm{H}_{2} \mathrm{O}$ during the methoxylation reaction, continued reaction with methanol is expected..$^{95}$

3. Hydrogen-Terminated Oxide Surfaces. The formation of hydrogen- or alkyl-terminated oxide surfaces has been the focus of many studies. Of critical importance to the resulting film structure $^{96,97}$ is the amount of water on the oxide surface prior to treatment. This water layer is usually at least several monolayers thick; ${ }^{43}$ suface-bound water cannot be fully removed without a high-temperature treatment, ${ }^{98}$ which can result in the dehydration of the oxide into strained siloxane bridges. ${ }^{95}$ The siloxane film is considered to be quite disordered with some $\mathrm{Si}-\mathrm{O}-\mathrm{Si}$ bonds linking neighboring molecules together and other $\mathrm{Si}-\mathrm{O}-\mathrm{Si}$ bonds linking some molecules to the surface.

Analogously, the FTIR spectrum of the TCS-treated oxide surface (Figure 6b) demonstrates the increase in at least two types of $\mathrm{Si}-\mathrm{O}-\mathrm{Si}$ bonds: some that are coupled in vibration to the $\mathrm{Si}-\mathrm{O}-\mathrm{Si}$ TO and LO modes of the surface oxide (1050 and $\left.1260 \mathrm{~cm}^{-1}\right)$, and some that are not coupled to these modes $\left(\sim 1090\right.$ and $\left.\sim 1160 \mathrm{~cm}^{-1}\right)$. Due to the close physical proximity required for mode coupling, as well as the nonreactivity of these modes with methanol (vida infra), we propose that the LO- and TO-coupled $\mathrm{Si}-\mathrm{O}-\mathrm{Si}$ modes result from TCS molecules that add $\mathrm{Si}-\mathrm{O}-\mathrm{Si}$ bonds that physically complete the bulk of the $\mathrm{SiO}_{2}$ matrix. Condensation reactions between hydrolyzed TCS molecules will likely form a $\mathrm{Si}-\mathrm{O}-\mathrm{Si}$ network that will not

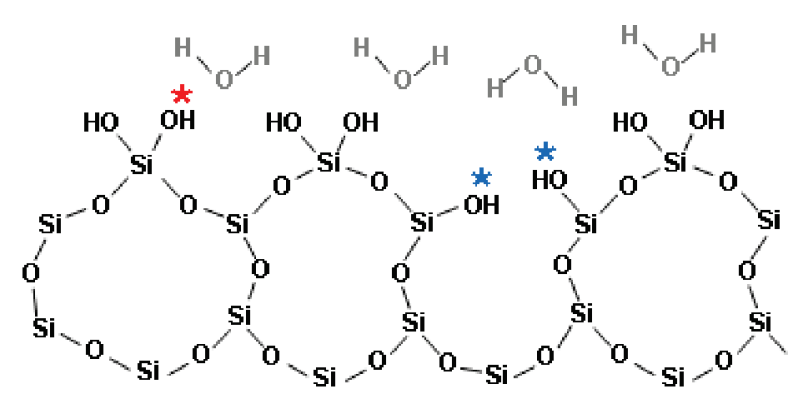

\section{1) $\operatorname{TCS}\left(\mathrm{Cl}_{3} \mathrm{SiH}\right)$ 2) Hydroxylaton}

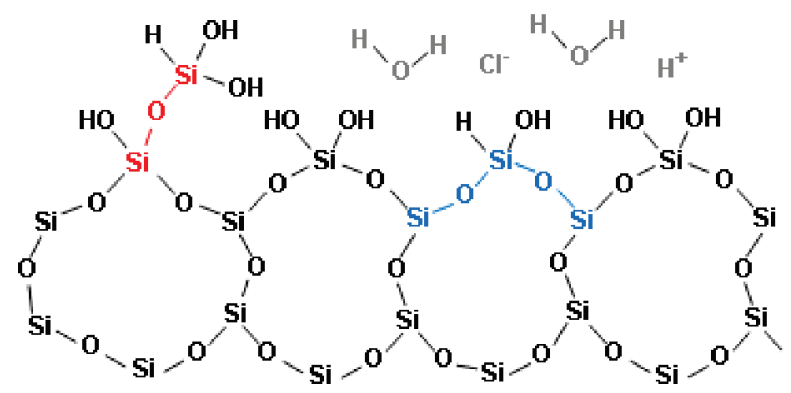

Figure 12. Schematic for the reaction of TCS with an oxide surface. TCS molecules reacting at the sites labeled by blue stars would complete an extended network of the $\mathrm{Si}-\mathrm{O}-\mathrm{Si}$ bulk, presumably increasing the absorption of the $\mathrm{SiO}_{2} \mathrm{LO}$ and TO modes. TCS molecules reacting at the red star may not lead to an increase in the LO and TO modes. Due to steric reasons, the blue $\mathrm{Si}-\mathrm{O}-\mathrm{Si}$ bonds would be less accessible for attack by $\mathrm{CH}_{3} \mathrm{OH}$ relative to the red $\mathrm{Si}-\mathrm{O}-\mathrm{Si}$ moiety. For clarity, this model is two-dimensional. ${ }^{99}$

couple to the bulk modes of the oxide surface. This concept is depicted graphically in Figure 12 in a two-dimensional format. ${ }^{99}$ When a molecule of TCS reacts at the positions indicated by the two blue stars, the two resulting $\mathrm{Si}-\mathrm{O}-\mathrm{Si}$ bonds complete an extended network of the bulk $\mathrm{SiO}_{2}$ matrix, increasing the absorption of the TO and $\mathrm{LO} \mathrm{Si-O}-\mathrm{Si}$ modes. If a free TCS molecule, or a cluster of condensed molecules, reacts at the single red star, an isolated $\mathrm{Si}-\mathrm{O}-\mathrm{Si}$ bond likely forms.

This assignment is based on the following reasons. First, sol-gel synthesis of silica from $\mathrm{Si}(\mathrm{OR})_{4}$ siloxanes is believed to produce ring structures with either 4 or $6 \mathrm{Si}-\mathrm{O}$ repeat units with a roughly $80-90 \%$ preference for the 4-ring species. ${ }^{100,101}$ The 4-ring structures have been reported to produce FTIR LO and TO modes at $\sim 1160$ and $\sim 1080 \mathrm{~cm}^{-1}$, respectively; these values are very similar to the uncoupled $\mathrm{Si}-\mathrm{O}-\mathrm{Si}$ modes observed in this work, implying that the TCS film is made of predominantly 4-ring structures. The 6-ring structures produce LO and TO modes at 1220 and $1040 \mathrm{~cm}^{-1}$, respectively. The mode observed at $\sim 1260 \mathrm{~cm}^{-1}$ (Figure $6 \mathrm{~b}$ ) is, thus, too high in energy to be explained by the presence of 6-ring structures. Second, the difference in reactivity of these modes is also consistent with the model of Figure 12. Baum and Schiffrin have proposed that the number of bonds to a crystal lattice restricts the ability of that silicon atom to engage in hypervalent transition states. ${ }^{102}$ The coupled $\mathrm{Si}-\mathrm{O}-\mathrm{Si}$ bonds, which are assumed to form a more intergral part of the physical $\mathrm{SiO}_{2}$ matrix, are expected to be less reactive toward methanol based on the difficulty of that $\mathrm{Si}$ atom to reach a pentavalent transistion state necessary for reaction (Figure 11). In contrast, the 


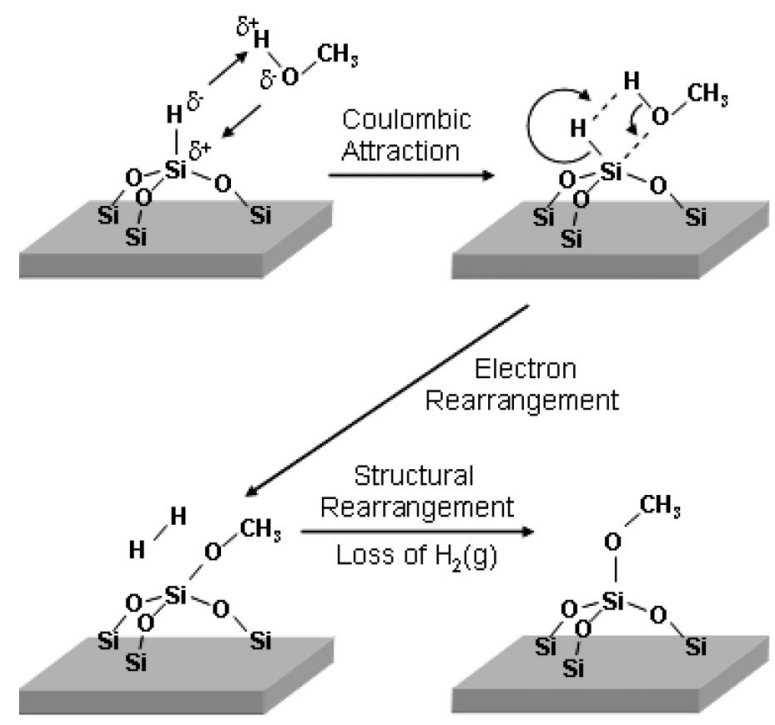

Figure 13. Possible mechanism for the reaction of a hydrogenterminated oxide surface site with methanol.

uncoupled $\mathrm{Si}-\mathrm{O}-\mathrm{Si}$ bonds have a much higher reactivity with methanol. This hypothesis is also consistent with DFT calculations. ${ }^{94}$ The energy needed to reach the transistion state for the reaction of a surface $\mathrm{Si}-\mathrm{OH}$ site of an oxide layer with methanol is within $5 \%$ of that needed for a free $\mathrm{Si}-\mathrm{O}-\mathrm{Si}$ group (not constrained by the geometry of an oxide lattice). Thus, it appears that it is the tight crystal structure of the $\mathrm{SiO}_{2}$ oxide matrix that prohibits the reaction of $\mathrm{CH}_{3} \mathrm{OH}$ (l) with the LO- and TOcoupled $\mathrm{Si}-\mathrm{O}-\mathrm{Si}$ bonds.

If the oscillator strengths of the coupled and uncoupled $\mathrm{Si}-\mathrm{O}-\mathrm{Si}$ species are similar, a simple area comparison suggests that the overlayer created by the TCS is not very densely packed and/or not very physically connected with the bulk of the surface oxide layer. (See the Supporting Information section for more information.) The bonding geometry of trichlorosilane molecules to oxide surfaces has been subject to significant debate. Some reports claim that no direct bonds to the oxide surface are formed, but rather a plane of polymerized siloxanes forms that is separated from the surface by a few monolayers of water. ${ }^{81,96}$ Meanwhile, other reports imply that a direct surface reaction has indeed occurred through X-ray photoelectron spectroscopy and secondary ion mass spectroscopy. ${ }^{41} \mathrm{We}$ believe that the increase in bulk $\mathrm{Si}-\mathrm{O}-\mathrm{Si}$ TO $\left(1050 \mathrm{~cm}^{-1}\right)$ and $\mathrm{LO}\left(1260 \mathrm{~cm}^{-1}\right)$ modes provides strong evidence for the formation of at least some direct bonding to the surface.

Upon the reaction of the hydrogen-terminated oxide surface with methanol, a significant portion of the $\mathrm{O}_{x} \mathrm{Si}-\mathrm{H}$ stretching, the $\mathrm{O}_{x} \mathrm{Si}-\mathrm{H}$ bending modes, and the isolated $\mathrm{Si}-\mathrm{O}-\mathrm{Si}$ modes disappear. These observations can be explained by two possible reaction mechanisms (Figures 13 and 14). In Figure 13, the atop $\mathrm{Si}-\mathrm{H}$ bond reacts exactly as has been proposed previously for $\mathrm{Si}-\mathrm{H}$ sites on an atomically smooth hydrogen-terminated Si(111) sample. ${ }^{59}$ Although this mechanism may be partly responsible for the observed loss in the $\mathrm{Si}-\mathrm{H}$ modes upon the reaction with methanol, it cannot explain the significant loss in the uncoupled $\mathrm{Si}-\mathrm{O}-\mathrm{Si}$ modes.

The mechanism in Figure 14 describes a possible reaction of methanol with the uncoupled $\mathrm{Si}-\mathrm{O}-\mathrm{Si}$ back bonds such that the $\mathrm{H}$-containing $\mathrm{Si}$ atom is removed (or etched) from the surface. ${ }^{103}$ The chemistry of the resulting surface site will be different, however, depending on which $\mathrm{Si}$ atom of the $\mathrm{Si}-\mathrm{O}-\mathrm{Si}$ back-bond is attacked by the methanol. The reaction pathway
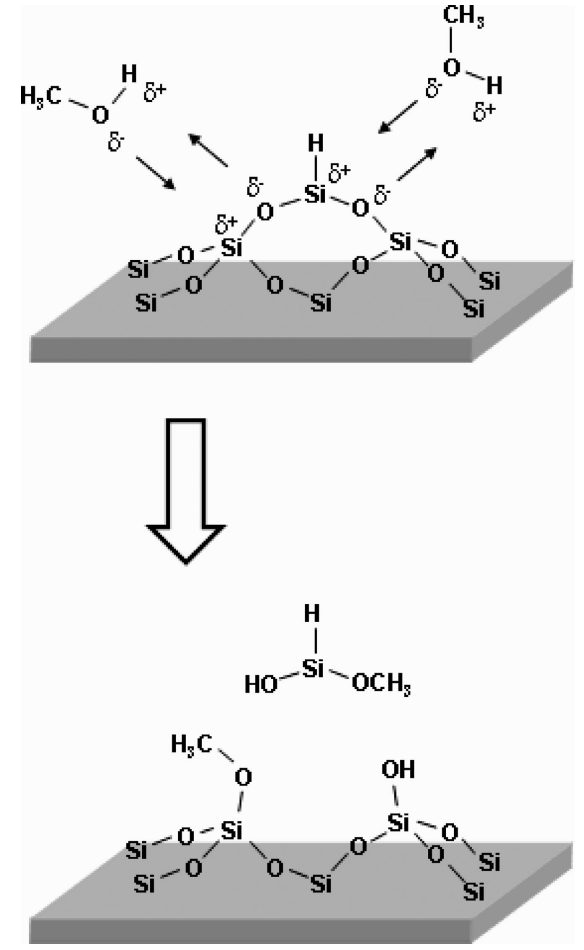

Figure 14. Possible mechanisms for the reaction of methanol with the hydrogen-terminated oxide surface in which the uncoupled/isolated $\mathrm{Si}-\mathrm{O}-\mathrm{Si}$ bonds are attacked. Depending on where the methanol attacks, the resulting surface site is either methoxy- or hydroxy-terminated. Since the silicon atom bound to $\mathrm{H}$ is removed from the surface in either case, a decrease in the $\mathrm{Si}-\mathrm{H}$ intensity is expected even if the $\mathrm{Si}-\mathrm{H}$ bond is not directly attacked. For clarity, the fourth bond of the atop silicon atom is omitted.

on the left depicts the electron pair of the oxygen atom in the methanol attacking the lower silicon atom, and the surface will be left with an atop $\mathrm{Si}-\mathrm{OCH}_{3}$ group. The remaining surface site is left hydroxyl terminated if the methanol attacks the atop silicon atom of the $\mathrm{Si}-\mathrm{O}-\mathrm{Si}$ linkage, as depicted by the pathway on the right. The remaining $\mathrm{Si}-\mathrm{OH}$ site could, however, react further with $\mathrm{CH}_{3} \mathrm{OH}$ (1) according to Figure 11. Thus, the hydrogen-terminated or hydroxy-terminated oxide surfaces result in similar FTIR signatures after reaction with methanol (Figure 7). Since the upper H-containing silicon atom is removed from the surface in either case, a decrease in the $\mathrm{Si}-\mathrm{H}$ intensity is expected even if the $\mathrm{Si}-\mathrm{H}$ bond is not directly attacked. Thus, we have no independent evidence that the mechanism presented in Figure 13 actually occurs under these conditions. For the purposes of investigating the reactivity of $\mathrm{O}_{x} \mathrm{Si}-\mathrm{H}$ sites with $\mathrm{CH}_{3} \mathrm{OH}(\mathrm{l})$, we suggest that future experiments be performed on $\mathrm{O}_{x} \mathrm{Si}-\mathrm{H}$ surfaces formed from the reaction of $\mathrm{H}-\mathrm{Si}(111)$ with $\mathrm{O}_{2}(\mathrm{~g})$ at elevated temperatures. ${ }^{76}$ Such surfaces are not expected to exhibit subsurface $\mathrm{Si}-\mathrm{O}-\mathrm{Si}$ reactivity with methanol, and reaction rates for atop $\mathrm{O}_{x} \mathrm{Si}-\mathrm{H}$ groups should be relatively uncomplicated.

The high reactivity of the isolated $\mathrm{Si}-\mathrm{O}-\mathrm{Si}$ species means that siloxane films made from similar trichlorosilane molecules will not lead to stable SAMs. If the $\mathrm{Si}-\mathrm{O}-\mathrm{Si}$ linkages must complete part of the bulk matrix of $\mathrm{SiO}_{2}$ in order to be stable, only a few linkers will remain after immersing the sample into an alcohol or any other $\mathrm{OH}$-containing liquid (such as $\mathrm{H}_{2} \mathrm{O}$ ).

4. Mechanisms for Subsurface Oxidation. The results presented thus far are consistent with the presence of $\mathrm{Si}-\mathrm{O}-\mathrm{Si}$ oxidation underneath atop $\mathrm{Si}-\mathrm{OCH}_{3}$ sites and not underneath $\mathrm{Si}-\mathrm{H}$ sites. This unusually high selectivity in the position of 


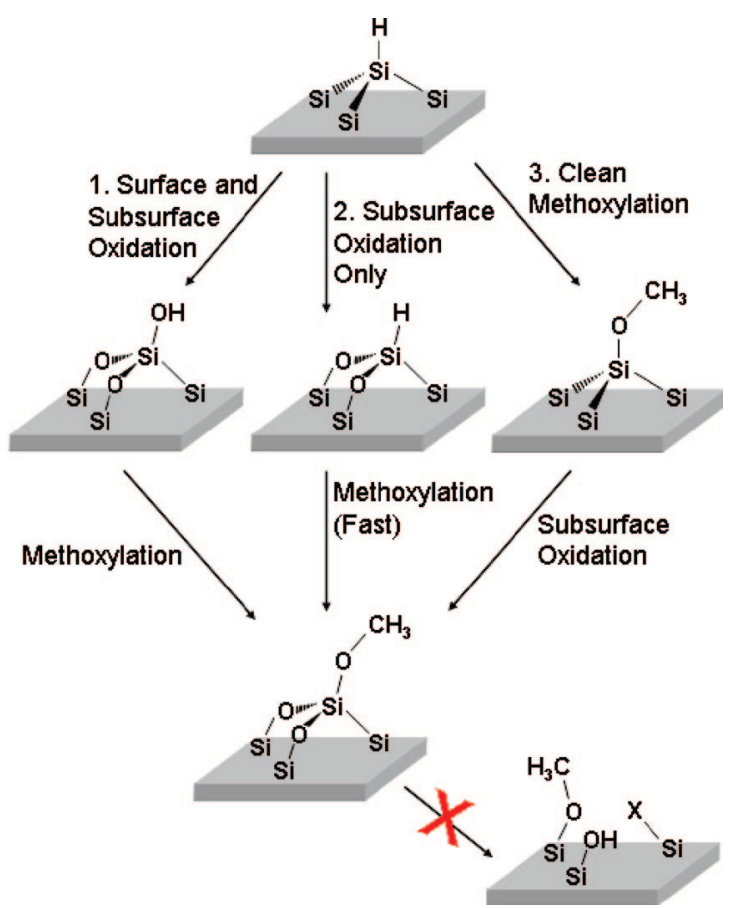

Figure 15. Possible mechanisms for the high selectivity of oxygen underneath regions of methoxyl groups. It seems extremely unlikely that methanol could further react with subsurface $\mathrm{Si}-\mathrm{O}-\mathrm{Si}$ bonds, as per Figure 14, because the resulting three functional groups, on the three subsurface silicon atoms, would have to fit into the space previously occupied by the single silicon atom.

the subsurface oxidation suggests that it has a chemical rather than a stochastic origin. The possible mechanisms for forming such a position-specific oxidation during the methanol reaction are outlined in Figure 15. Pathway 1 depicts the possibility that oxide-free $\mathrm{H}-\mathrm{Si}(111)$ samples could be oxidized first (by any impurities such as $\mathrm{O}_{2}$ or $\mathrm{H}_{2} \mathrm{O}$ ), such that both the subsurface $\mathrm{Si}-\mathrm{Si}$ bonds and the atop $\mathrm{Si}-\mathrm{H}$ bond are oxidized to $\mathrm{Si}-\mathrm{O}-\mathrm{Si}$ and $\mathrm{Si}-\mathrm{OH}$ species, respectively. This hydroxy-terminated surface site can then be methoxylated as described in Figure 11. Increases in the $\mathrm{SiO}-\mathrm{H}$ stretching mode (around $3700 \mathrm{~cm}^{-1}$ ) have not been reliably observed, but difficulties in the water vapor subtraction within this region do not allow for a conclusive argument from our data to be made. Similarly, the bending mode for $\mathrm{SiO}-\mathrm{H}$ groups, around $800-1000 \mathrm{~cm}^{-1}$, has also never been observed for any of the (nonoxide-terminated) samples studied in this work, but this mode is expected to be fairly weak and broad. Thus, a significant surface concentration of the $\mathrm{O}_{x} \mathrm{Si}-\mathrm{OH}$ intermediate may fall below the detection limit. Pathway 2 depicts the possible mechanism in which only the subsurface $\mathrm{Si}-\mathrm{Si}$ back bonds are oxidized to form a $\mathrm{O}_{x} \mathrm{Si}-\mathrm{H}$ site. This atop $\mathrm{Si}-\mathrm{H}$ bond can then react with methanol as described in Figure 13. If this mechanism does occur, the reactivity of the $\mathrm{O}_{x} \mathrm{Si}-\mathrm{H}$ site to methanol must be significantly fast since no $\mathrm{O}_{x} \mathrm{Si}-\mathrm{H}$ bonds are observed experimentally; in this case, the sensitivity for the detection of $\mathrm{O}_{x} \mathrm{Si}-\mathrm{H}$ bonds is fairly high since the stretching mode is relatively intense (Figure 6b). Pathway 3 depicts the possibility that an oxide-free $\mathrm{Si}-\mathrm{OCH}_{3}$ surface site is created first, but the presence of the electronegative $\mathrm{O}$ atom weakens the $\mathrm{Si}-\mathrm{Si}$ back bonds such that oxidation is facilitated after methoxylation. ${ }^{104-108}$ Based on the steric and lattice arguments of Baum and Schiffrin, it seems extremely unlikely that methanol could further react with the subsurface $\mathrm{Si}-\mathrm{O}-\mathrm{Si}$ back bonds, which are already more strained the individual $\mathrm{Si}-\mathrm{Si}$ back bonds. This hypothesis is in agreement with the result that a partially oxidized methoxyl surface exposed to $65{ }^{\circ} \mathrm{C}$ methanol for $10 \mathrm{~h}$ did not remove any $\mathrm{Si}-\mathrm{O}-\mathrm{Si}$ (Figure 8b).

\section{Conclusions}

Atomically smooth hydrogen-terminated $\mathrm{Si}(111)$ surfaces present a homogeneous bonding environment that, when coupled with high resolution FTIR measurements and a small reactant such as methanol, allow an investigation of the subtle shifts in vibrational modes that can unlock several key aspects regarding the chemistry of silicon surfaces. Specifically, homogeneous $\mathrm{Si}(111)$ surfaces with $\sim 30 \% \mathrm{Si}-\mathrm{OCH}_{3}$ and $\sim 70 \% \mathrm{Si}-\mathrm{H}$ sites have been generated with no detectable subsurface oxidation (less than $3 \%$ of a monolayer) using a $65^{\circ} \mathrm{C}$ reaction in neat $\mathrm{CH}_{3} \mathrm{OH}$ (1). Such surfaces display vibrational modes that are sufficiently sharp to allow quantitative comparison with similarly reacted $\mathrm{SiO}_{2}$ surfaces. Subsurface oxidation has been observed for room temperature reactions with neat alcohol, or upon deliberate exposure of methoxylated surfaces to laboratory air followed by a subsequent exposure to neat $\mathrm{CH}_{3} \mathrm{OH}$. The FTIR spectra of these oxide-containing samples all display blue-shifted components of the complex $\mathrm{O}-\mathrm{C}$, umbrella $\mathrm{CH}_{3}$, and $\mathrm{C}-\mathrm{H}$ stretching modes. These modes are assigned to $\mathrm{O}_{x} \mathrm{Si}-\mathrm{OCH}_{3}$ sites and are corroborated by DFT calculations. While it is unclear what fraction of surface oxide may by hydroxy-terminated (based on a low sensitivity for this surface species), we have demonstrated experimentally that oxide, when present, is at least partially terminated by $\mathrm{Si}-\mathrm{OCH}_{3}$ sites and not $\mathrm{Si}-\mathrm{H}$ sites. In contrast to $\mathrm{H}-\mathrm{Si}(111)$ surfaces, $\mathrm{H}-\mathrm{Si}(100)$ surfaces under the same reaction conditions exhibit significant surface oxidization. The lower reactivity, more-controllable, and atomically smooth Si(111) surface thus demonstrates superior properties that can be harnessed for nanoelectronic applications. Finally, hydrogenterminated oxide surfaces formed with trichlorosilane are quite unstable upon exposure to methanol.

Acknowledgment. We acknowledge the support of the National Science Foundation, through Grant CHE-0415652 at Rutgers and UT Dallas, and through the U.S.-France cooperative research program (NSF-INT-0341053) for facilitating the international collaboration with the LAAS at Toulouse, and associated CALMIP computer resources. The authors are grateful to Nathan S. Lewis for stimulating discussions.

Supporting Information Available: Additional experimental details and analysis. This material is available free of charge via the Internet at http://pubs.acs.org.

\section{References and Notes}

(1) Eades, W. D.; Swanson, R. M. J. Appl. Phys. 1985, 58, 4267. 1055 .

(2) Nicollian, E. H.; Goetzberger, A. Bell Syst. Tech. J. 1967, 46,

(3) Royea, W. J.; Michalak, D. J.; Lewis, N. S. Appl. Phys. Lett. 2000, $77,2566$.

(4) Janshoff, A.; Dancil, K. P. S.; Steinem, C.; Greiner, D. P.; Lin, V. S. Y.; Gurtner, C.; Motesharei, K.; Sailor, M. J.; Ghadiri, M. R. J. Am. Chem. Soc. 1998, 120, 12108.

(5) Canham, L. T.; Stewart, M. P.; Buriak, J. M.; Reeves, C. L.; Anderson, M.; Squire, E. K.; Allcock, P.; Snow, P. A. Phys. Status Solidi A-Appl. Res. 2000, 182, 521.

(6) Haick, H.; Hurley, P. T.; Hochbaum, A. I.; Yang, P. D.; Lewis, N. S. J. Am. Chem. Soc. 2006, $128,8990$.

(7) Buriak, J. M. Chem. Rev. 2002, 102, 1271.

(8) Filler, M. A.; Bent, S. F. Prog. Surf. Sci. 2003, 73, 1.

(9) Webb, L. J.; Lewis, N. S. J. Phys. Chem. B 2003, 107, 5404.

(10) Webb, L. J.; Nemanick, E. J.; Biteen, J. S.; Knapp, D. W.; Michalak, D. J.; Traub, M. C.; Chan, A. S. Y.; Brunschwig, B. S.; Lewis, N. S. J. Phys. Chem. B 2005, 109, 3930 
(11) Webb, L. J.; Rivillon, S.; Michalak, D. J.; Chabal, Y. J.; Lewis, N. S. J. Phys. Chem. B 2006, 110, 7349.

(12) Sieval, A. B.; Huisman, C. L.; Schonecker, A.; Schuurmans, F. M.; van der Heide, A. S. H.; Goossens, A.; Sinke, W. C.; Zuilhof, H.; Sudholter, E. J. R. J. Phys. Chem. B 2003, 107, 6846

(13) Nemanick, E. J.; Hurley, P. T.; Brunschwig, B. S.; Lewis, N. S. J. Phys. Chem. B 2006, 110, 14800.

(14) Nemanick, E. J.; Hurley, P. T.; Webb, L. J.; Knapp, D. W.; Michalak, D. J.; Brunschwig, B. S.; Lewis, N. S. J. Phys. Chem. B 2006, $110,14770$.

(15) Webb, L. J.; Michalak, D. J.; Biteen, J. S.; Brunschwig, B. S.; Chan, A. S. Y.; Knapp, D. W.; Meyer, H. M.; Nemanick, E. J.; Traub, M. C.; Lewis, N. S. J. Phys. Chem. B 2006, 110, 23450.

(16) Dancil, K. P. S.; Greiner, D. P.; Sailor, M. J. J. Am. Chem. Soc. 1999, 121,7925

(17) Maldonado, S.; Plass, K. E.; Knapp, D.; Lewis, N. S. J. Phys. Chem. C 2007, 111, 17690 .

(18) Smalley, J. F.; Sachs, S. B.; Chidsey, C. E. D.; Dudek, S. P.; Sikes, H. D.; Creager, S. E.; Yu, C. J.; Feldberg, S. W.; Newton, M. D. J. Am. Chem. Soc. 2004, 126, 14620.

(19) Cheng, J.; Robinson, D. B.; Cicero, R. L.; Eberspacher, T.; Barrelet, C. J.; Chidsey, C. E. D. J. Phys. Chem. B 2001, 105, 10900.

(20) Barrelet, C. J.; Robinson, D. B.; Cheng, J.; Hunt, T. P.; Quate, C. F.; Chidsey, C. E. D. Langmuir 2001, 17, 3460.

(21) Sailor, M. J.; Lee, E. J. Adv. Mater. 1997, 9, 783.

(22) Pomykal, K. E.; Fajardo, A. M.; Lewis, N. S. J. Phys. Chem. 1995, 99, 8302 .

(23) Parker, E. E.; Ashurst, W. R.; Carraro, C.; Maboudian, R. J. Microelectromech. Syst. 2005, 14, 947. 35 .

(24) Maboudian, R.; Carraro, C. Annu. Rev. Phys. Chem. 2004, 55,

(25) Ashurst, W. R.; Carraro, C.; Maboudian, R.; Frey, W. Sens. Actuators A-Phys. 2003, 104, 213.

(26) Ciampi, S.; Bocking, T.; Kilian, K. A.; James, M.; Harper, J. B.; Gooding, J. J. Langmuir 2007, 23, 9320.

(27) Waggoner, P. S.; Craighead, H. G. Lab Chip 2007, 7, 1238.

(28) Yin, H. B.; Brown, T.; Greef, R.; Wilkinson, J. S.; Melvin, T. Microelectron. Eng. 2004, 73-74, 830.

(29) Boukherroub, R.; Wayner, D. D. M. J. Am. Chem. Soc. 1999, 121,11513

(30) Asanuma, H.; Lopinski, G. P.; Yu, H. Z. Langmuir 2005, 21, 5013.

(31) Voicu, R.; Boukherroub, R.; Bartzoka, V.; Ward, T.; Wojtyk,

J. T. C.; Wayner, D. D. M. Langmuir 2004, 20, 11713.

(32) Frechette, J.; Maboudian, R.; Carraro, C. J. Microelectromech. Syst. 2006, 15, 737.

(33) Frechette, J.; Maboudian, R.; Carraro, C. Langmuir 2006, 22, 2726.

(34) Etienne, M.; Walcarius, A. Talanta 2003, 59, 1173.

(35) Wang, J.; Guo, D. J.; Xia, B.; Chao, J.; Xiao, S. J. Colloids Surf. A 2007, 305, 66 .

(36) Eves, B. J.; Fan, C. Y.; Lopinski, G. P. Small 2006, 2, 1379.

(37) Brewer, R. T.; Ho, M. T.; Zhang, K. Z.; Goncharova, L. V.; Starodub, D. G.; Gustafsson, T.; Chabal, Y. J.; Moumen, N. Appl. Phys. Lett. 2004, 85, 3830.

(38) Nemanick, E. J.; Solares, S. D.; Goddard, W. A.; Lewis, N. S. J. Phys. Chem. B 2006, 110, 14842.

(39) Wen, Y. Q.; Yi, W. H.; Meng, L. J.; Feng, M.; Jiang, G. Y.; Yuan, W. F.; Zhang, Y. Q.; Gao, H. J.; Jiang, L.; Song, Y. L. J. Phys. Chem. B 2005, 109,14465

(40) Elmore, D. L.; Chase, D. B.; Liu, Y. J.; Rabolt, J. F. Vib. Spectrosc. 2004, 34, 37 2965.

(41) Rye, R. R.; Nelson, G. C.; Dugger, M. T. Langmuir 1997, 13 ,

(42) Jal, P. K.; Patel, S.; Mishra, B. Talanta 2004, 62, 1005.

(43) Allara, D. L.; Parikh, A. N.; Rondelez, F. Langmuir 1995, 11, 2357.

(44) Jeon, N. L.; Choi, I. S.; Whitesides, G. M.; Kim, N. Y.; Laibinis, P. E.; Harada, Y.; Finnie, K. R.; Girolami, G. S.; Nuzzo, R. G. Appl. Phys. Lett. 1999, 75, 4201 .

(45) Boukherroub, R.; Morin, S.; Sharpe, P.; Wayner, D. D. M.; Allongue, P. Langmuir 2000, 16, 7429.

(46) Chazalviel, J. N. J. Electroanal. Chem. 1987, 233, 37.

(47) Warntjes, M.; Vieillard, C.; Ozanam, F.; Chazalviel, J. N. J. Electrochem. Soc. 1995, 142, 4138.

(48) Cleland, G.; Horrocks, B. R.; Houlton, A. J. Chem. Soc.-Faraday Trans. 1995, 91, 4001.

(49) Bateman, J. E.; Eagling, R. D.; Horrocks, B. R.; Houlton, A. J. Phys. Chem. B 2000, 104, 5557.

(50) Bateman, J. E.; Horrocks, B. R.; Houlton, A. J. Chem. SocFaraday Trans. 1997, 93, 2427.

(51) Haber, J. A.; Lauermann, I.; Michalak, D.; Vaid, T. P.; Lewis, N. S. J. Phys. Chem. B 2000, 104, 9947.

(52) Hacker, C. A.; Anderson, K. A.; Richter, L. J.; Richter, C. A. Langmuir 2005, 21, 882 .
(53) Zhu, X. Y.; Boiadjiev, V.; Mulder, J. A.; Hsung, R. P.; Major, R. C. Langmuir 2000, 16, 6766.

(54) Higashi, G. S.; Becker, R. S.; Chabal, Y. J.; Becker, A. J. Appl. Phys. Lett. 1991, 58, 1656.

(55) Langner, A.; Panarello, A.; Rivillon, S.; Vassylyev, O.; Khinast, J. G.; Chabal, Y. J. J. Am. Chem. Soc. 2005, 127, 12798.

(56) Newton, T. A.; Huang, Y. C.; Lepak, L. A.; Hines, M. A. J. Chem. Phys. 1999, 111, 9125.

(57) Bomchil, G.; Herino, R.; Barla, K.; Pfister, J. C. J. Electrochem. Soc. $1983,130,1611$

(58) Kang, C. G.; Kang, M. S.; Yang, J. H.; Jin, J. H.; Hong, S. I.; Min, N. K. J. Korean Phys. Soc. 2003, 42, S693.

(59) Michalak, D. J.; Rivillon, S.; Chabal, Y. J.; Esteve, A.; Lewis, N. S. J. Phys. Chem. B 2006, 110, 20426.

(60) This detection limit was calculated using the average noise rootmean-square amplitude of $0.018 \mathrm{mAU}$ over the spectral region of 920$1060 \mathrm{~cm}^{-1}$ for the oxide-free $\mathrm{Si}-\mathrm{OCH}_{3}$ samples and the $1.5 \mathrm{mAU}$ intensity of the $\mathrm{Si}-\mathrm{O}-\mathrm{Si} \mathrm{TO}$ mode $\left(\sim 1050 \mathrm{~cm}^{-1}\right)$ observed on an SC1/SC2-cleaned surface that has a $\sim 6-\AA \AA$ ( $\sim 2$ monolayer $)$ thick oxide based on the $\mathrm{Si}-\mathrm{O}-$ Si LO frequency of $1220 \mathrm{~cm}^{-1}$ (ref 71). An accurate calculation of the detection limit is difficult because the spectral features of the $\mathrm{Si}-\mathrm{O}-\mathrm{Si}$ TO mode may not remain linear with surface coverage at submonolayer concentrations.

(61) Higashi, G. S.; Chabal, Y. J.; Trucks, G. W.; Raghavachari, K. Appl. Phys. Lett. 1990, 56, 656.

(62) Hines, M. A. Annu. Rev. Phys. Chem. 2003, 54, 29

(63) Frisch, M. J.; Trucks, G. W.; Schlegel, H. B.; Scuseria, G. E.; Robb, M. A.; Cheeseman, J. R.; Montgomery, J. A.; Vreven, T.N., K. K.; Burant, J. C.; Millam, J. M.; Iyengar, S. S.; Tomasi, J.; Barone, V.; Mennucci, B.; Cossi, M.; Scalmani, G.; Rega, N.; Petersson, G. A.; Nakatsuji, H.; Hada, M.; Ehara, M.; Toyota, K.; Fukuda, R.; Hasegawa, J.; Ishida, M.; Nakajima, T.; Honda, Y.; Kitao, O.; Nakai, H.; Klene, M.; Li, X; Knox, J. E.; Hratchian, H. P.; Cross, J. B.; Adamo, C.; Jaramillo, J.; Gomperts, R.; Stratmann, R. E.; Yazyev, O.; Austin, A. J.; Cammi, R.; Pomelli, C.; Ochterski, J. W.; Ayala, P. Y; Morokuma, K.; Voth, G. A.; Salvador, P.; Dannenberg, J. J.; Zakrzewski, V. G.; Dapprich, S.; Daniels, A. D.; Strain, M. C.; Farkas, O.; Malick, D. K.; Rabuck, A. D.; Raghavachari, K.; Foresman, J. B.; Ortiz, J. V.; Cui, Q.; Baboul, A. G.; Clifford, S.; Cioslowski, J; Stefanov, B. B.; Liu, G.; Liashenko, A.; Piskorz, P.; Komaromi, I.; Martin, R. L; Fox, D. J.; Keith, T.; Al-Laham, M. A.; Peng, C. Y.; Nanayakkara, A.; Challacombe, M.; Gill, P. M. W.; Johnson, B.; Chen, W.; Wong, M. W.; Gonzalez, C.; Pople, J. A. Gaussian 03, revision B.05; Gaussian, Inc.: Pittsburgh, PA, 2003.

(64) Becke, A. D. J. Chem. Phys. 1993, 98, 5648.

(65) Lee, C. T.; Yang, W. T.; Parr, R. G. Phys. Rev. B 1988, 37, 785.

(66) Pelmenschikov, A. G.; Morosi, G.; Gamba, A.; Zecchina, A.; Bordiga, S.; Paukshtis, E. A. J. Phys. Chem. 1993, 97, 11979.

(67) Jakob, P.; Chabal, Y. J.; Raghavachari, K. Chem. Phys. Lett. 1991, 187,325

(68) Jakob, P.; Chabal, Y. J.; Raghavachari, K.; Christman, S. B. Phys. Rev. B 1993, 47, 6839.

(69) Jakob, P.; Chabal, Y. J.; Raghavachari, K.; Dumas, P.; Christman, S. B. Surf. Sci. 1993, 285, 251.

(70) Luo, H. H.; Chidsey, C. E. D. Appl. Phys. Lett. 1998, 72, 477.

(71) Queeney, K. T.; Chabal, Y. J.; Weldon, M. K.; Raghavachari, K. Phys. Status Solidi A-Appl. Res. 1999, 175, 77.

(72) Queeney, K. T.; Herbots, N.; Shaw, J. M.; Atluri, V.; Chabal, Y. J. Appl. Phys. Lett. 2004, 84, 493.

(73) Queeney, K. T.; Weldon, M. K.; Chang, J. P.; Chabal, Y. J.; Gurevich, A. B.; Sapjeta, J.; Opila, R. L. J. Appl. Phys. 2000, 87, 1322.

(74) Weldon, M. K.; Queeney, K. T.; Chabal, Y. J.; Stefanov, B. B.; Raghavachari, K. J. Vac. Sci. Technol. B 1999, 17, 1795.

(75) Neuwald, U.; Hessel, H. E.; Feltz, A.; Memmert, U.; Behm, R. J. Appl. Phys. Lett. 1992, 60, 1307.

(76) Zhang, X.; Chabal, Y. J.; Christman, S. B.; Chaban, E. E.; Garfunkel, E. J. Vac. Sci. Technol. A 2001, 19, 1725.

(77) At this point, we are unable to determine if the consistent absence of $\mathrm{Si}-\mathrm{O}-\mathrm{Si}$ modes observed at $65^{\circ} \mathrm{C}$ is due to inherent chemical or kinetic reasons, lower gas solubility at elevated temperatures, or enhanced cleanliness of the glassware due to the rinsing treatment with hot methanol. Nevertheless, the spectra demonstrate that it is possible to generate a methoxylated surface without any detectable oxide.

(78) The $\mathrm{Si}(100)$ surface is considerably more rough than the $\mathrm{Si}(111)$ surface, so the increase in intensity of these modes may not necessarily correspond to a higher coverage per available surface sites. In addition, the orientation of the resulting $\mathrm{Si}-\mathrm{OCH}_{3}$ species with repect to the surface normal may also be different for the two surfaces, and this could lead to changes in the infrared absorption for a given light incidence angle even for the same surface coverage. Finally, the higher reactivity of the Si(100) surface could presumably lead to a higher coverage of $\mathrm{Si}-\mathrm{OCH}_{3}$ sites. For these reasons, a direct comparison of the surface coverage of $\mathrm{Si}-\mathrm{OCH}_{3}$ sites for the $\mathrm{Si}(111)$ and $\mathrm{Si}(100)$ surfaces based on the data presented herein is not trivial. 
(79) Chabal, Y. J.; Higashi, G. S.; Raghavachari, K.; Burrows, V. A. J. Vac. Sci. Technol. A 1989, 7, 2104.

(80) Dumas, P.; Chabal, Y. J.; Jakob, P. Surf. Sci. 1992, 270, 867.

(81) Tripp, C. P.; Hair, M. L. Langmuir 1995, 11, 149.

(82) This decrease in $\mathrm{Si}-\mathrm{OH}$ mode is surprising because hydrolyzed TCS molecules have $3 \mathrm{Si}-\mathrm{OH}$ groups per molecule. Thus, a decrease in the $\mathrm{Si}-\mathrm{OH}$ mode intensity either implies that the unreacted $\mathrm{Si}-\mathrm{OH}$ modes are highly screened out by the oxide film or that the siloxane film is highly crosslinked (more than two $\mathrm{Si}-\mathrm{OH}$ sites per TCS molecule are condensed to form the $\mathrm{Si}-\mathrm{O}-\mathrm{Si}$ network).

(83) Upon closer inspection, spectra a and c in Figure 8 do contain small components of blue shifted modes which may indicate that the surface is not entirely oxide free; an analysis of the amount of blue-shifted modes may thus provide a lower detection limit on amount of subsurface oxidation than the presence of $\mathrm{Si}-\mathrm{O}-\mathrm{Si} \mathrm{LO}$ and $\mathrm{TO}$ modes. 87.

(84) Rivillon, S.; Brewer, R. T.; Chabal, Y. J. Appl. Phys. Lett. 2005,

(85) Rao, G. R.; Wang, Z. H.; Watanabe, H.; Aoyagi, M.; Urisu, T. Surf. Sci. 2004, 570, 178.

(86) Zhang, X.; Garfunkel, E.; Chabal, Y. J.; Christman, S. B.; Chaban, E. E. Appl. Phys. Lett. 2001, 79, 4051.

(87) Queeney, K. T.; Weldon, M. K.; Chabal, Y. J.; Raghavachari, K. J. Chem. Phys. 2003, 119, 2307.

(88) Gstrein, F.; Michalak, D. J.; Royea, W. J.; Lewis, N. S. J. Phys. Chem. B 2002, 106, 2950. 4689.

(89) Rosenbluth, M. L.; Lewis, N. S. J. Am. Chem. Soc. 1986, 108,

(90) A long-range periodicity as described in Figure 9 would require one of two possibilities. First, for a terrace-top reaction mechanism, the reactivity of a lone $\mathrm{Si}-\mathrm{H}$ site must be much less than the reactivity of a second-nearest-neighbor $\mathrm{Si}-\mathrm{H}$ site to a $\mathrm{Si}-\mathrm{OCH}_{3}$ group (i.e., such that the nucleation rate is slow relative to the growth of a domain edge). Possibilities for such selectivity include an increased polarization of the second-nearest-neighbor $\mathrm{Si}-\mathrm{H}$ group due to the presence of the $\mathrm{Si}-\mathrm{O}$ bond of the $\mathrm{Si}-\mathrm{OCH}_{3}$ group, or the increased residence time of the solutionphase methanol molecule at the second-nearest-neighbor site based on van der Waals attraction between two $\mathrm{CH}_{3}$ groups. The polarization of the second nearest neighbor $\mathrm{Si}-\mathrm{H}$ group is expected to be small; periodic boundary array calculations by Solares et al. (ref 91) show that the atomic charge on a silicon atom four lattice sites into the crystal (which corresponds to the same distance as a second nearest neighbor atop site) is negligible. Both the $\mathrm{CH}_{3}$ terminus of the $\mathrm{Si}-\mathrm{OCH}_{3}$ group and the $\mathrm{Si}-\mathrm{H}$ sites of the surface are non-polar so a significantly larger residence time of a $\mathrm{CH}_{3} \mathrm{OH}$ molecule near the $\mathrm{Si}-\mathrm{OCH}_{3}$ site seems unlikely. Reactions on the terrace top, thus seem unlikey to lead to any long range periodicity. Second, a step-flow mechanism for the formation of methoxyl-terminated surfaces has been proposed by Michalak et al. (ref 59). Steric limitations along the step edge during the putative step-flow reaction, if it occurs, could however lead to a more periodic surface coverage.

(91) Solares, S. D.; Michalak, D. J.; Goddard, W. A.; Lewis, N. S. J. Phys. Chem. B 2006, 110, 8171.

(92) Chuit, C.; Corriu, R. J. P.; Reye, C.; Young, J. C. Chem. Rev. 1993, 93, 1371.

(93) Hines, M. A.; Chabal, Y. J.; Harris, T. D.; Harris, A. L. J. Chem. Phys. 1994, 101, 8055.

(94) Natal-Santiago, M. A.; Dumesic, J. A. J. Catal. 1998, 175, 252.

(95) Wovchko, E. A.; Camp, J. C.; Glass, J. A.; Yates, J. T. Langmuir $1995,11,2592$.

(96) Tripp, C. P.; Hair, M. L. Langmuir 1992, 8, 1120.

(97) Parikh, A. N.; Allara, D. L.; Azouz, I. B.; Rondelez, F. J. Phys. Chem. 1994, 98, 7577.

(98) Zhuravlev, L. T. Langmuir 1987, 3, 316.

(99) An accurate representation of a three dimensional oxide surface would have an average of 4 oxygen atoms around each silicon atom and two silicon atoms around each oxygen atom.

(100) Fidalgo, A.; Ciriminna, R.; Ilharco, L. M.; Pagliaro, M. Chem. Mater. 2005, 17, 6686.

(101) Fidalgo, A.; Ilharco, L. M. Chem.-Eur. J. 2004, 10, 392

(102) Baum, T.; Schiffrin, D. J. J. Chem. Soc.-Faraday Trans. 1998, 94, 691.

(103) For clarity, the fourth bond of the silicon atom in the atop $\mathrm{Si}-\mathrm{H}$ site of Figure 13 was removed. In addition, Figure 13 is not intending to imply that silicon atop sites that contain two $\mathrm{Si}-\mathrm{O}-\mathrm{Si}$ linkages with the surface are reactive; such a geometry may already present a transition state that is too sterically inhibited to allow either of these mechanisms to occur.

(104) Zhang, R. Q.; Zhao, Y. L.; Teo, B. K. Phys. Rev. B 2004, 69.

(105) Allongue, P.; Costa Kieling, V.; Gerischer, H. J. Electrochem. Soc. 1993, 140, 1009.

(106) Allongue, P.; Costa Kieling, V.; Gerischer, H. J. Electrochem. Soc. 1993, 140, 1018 .

(107) Allongue, P.; Kieling, V.; Gerischer, H. Electrochim. Acta 1995, 40, 1353.

(108) Allongue, P.; Kieling, V.; Gerischer, H. J. Phys. Chem. 1995, 99 , 9472.

(109) Amy, S. R.; Michalak, D. J.; Chabal, Y. J.; Wielunski, L.; Hurley, P. T.; Lewis, N. S. J. Phys. Chem. C 2007, 111, 13053.

\section{JP8030539}

